\title{
Histone Lysine Demethylase Inhibitors
}

\author{
Ashwini Jambhekar, ${ }^{1}$ Jamie N. Anastas, ${ }^{1,2}$ and Yang Shi ${ }^{1,2}$ \\ ${ }^{1}$ Division of Newborn Medicine and Epigenetics Program, Department of Medicine, Boston Children's \\ Hospital, Boston, Massachusetts 02115 \\ ${ }^{2}$ Department of Cell Biology, Harvard Medical School, Boston, Massachusetts 02115 \\ Correspondence: yang.shi@childrens.harvard.edu
}

The dynamic regulation of covalent modifications to histones is essential for maintaining genomic integrity and cell identity and is often compromised in cancer. Aberrant expression of histone lysine demethylases has been documented in many types of blood and solid tumors, and thus demethylases represent promising therapeutic targets. Recent advances in high-throughput chemical screening, structure-based drug design, and structure-activity relationship studies have improved both the specificity and the in vivo efficacy of demethylase inhibitors. This review will briefly outline the connection between demethylases and cancer and will provide a comprehensive overview of the structure, specificity, and utility of currently available demethylase inhibitors. To date, a select group of demethylase inhibitors is being evaluated in clinical trials, and additional compounds may soon follow from the bench to the bedside.

\section{THE DYNAMIC NATURE OF HISTONE METHYLATION}

Chromatin, which is mainly composed of DNA and histone proteins, is the template on which many important nuclear processes take place, including transcription and DNA replication. Chromatin consists of repeating units of nucleosomes, comprising 147 base pairs of DNA wrapped around an octamer of histones (typically two each of histones $\mathrm{H} 2 \mathrm{~A}, \mathrm{H} 2 \mathrm{~B}, \mathrm{H} 3$, and H4) (Luger et al. 1997), which are then further compacted into higher order structures. The histones themselves, particularly $\mathrm{H} 3$ and $\mathrm{H} 4$, are subject to extensive chemical modifications such as phosphorylation, ubiquitination, acetylation, and methylation (Jenuwein and Al- lis 2001), which have profound effects on gene expression. Consequently, the mechanisms that regulate these modifications are relevant to many areas of biology. The effects of histone methylation, which occurs primarily on arginines and lysines, depend on the site of modification, the extent of methylation, as well as on additional modifications on the same or neighboring histones (Kouzarides 2007). Patterns of nucleosome methylation affect gene expression, replication, the maintenance of genome stability, and other DNA metabolic processes; thus, the mechanisms that regulate histone methylation are relevant to both normal development and diseases like cancer.

As methylation marks are quite stable, they were initially considered to be irreversible. Early

Editors: Scott A. Armstrong, Steven Henikoff, and Christopher R. Vakoc

Additional Perspectives on Chromatin Deregulation in Cancer available at www.perspectivesinmedicine.org

Copyright (C) 2017 Cold Spring Harbor Laboratory Press; all rights reserved; doi: 10.1101/cshperspect.a026484

Cite this article as Cold Spring Harb Perspect Med 2017;7:a026484 
A. Jambhekar et al.

models for reversal of histone methylation invoked clipping of modified histone tails or replacement of entire histones, although both failed to explain the rapid changes in histone modifications observed in vivo (Bannister et al. 2002). However, an early study measured formaldehyde production as an indication for possible histone demethylase activity and found potential activities primarily in the kidney (Paik and Kim 1973). However, it was unclear whether formaldehyde production was the direct action of a demethylase, and no evidence was provided for the resulting demethylated histones, or for the molecular nature/mechanism of the demethylase enzyme. The first irrefutable evidence that methylation could be dynamically regulated came in 2004 with the discovery of the lysine-specific demethylase LSD1 (also known as KDM1A) (Shi et al. 2004). Similar to monoamine oxidases (MAOs), LSD1 uses FAD as a cofactor to oxidize the methyl group and hydrolyze it to formaldehyde (Fig. 1A). This mechanism precludes the use of trimethylated lysine as a substrate, which does not contain a free electron pair required for the first step of the reaction. Accordingly, LSD1 demethylates H3K4me1/2, but not H3K4me3, or other methylated lysines in $\mathrm{H} 3$ such as H3K20me2 (Shi et al. 2004). In prostate cancer cells, LSD1 also demethylates $\mathrm{H} 3 \mathrm{~K} 9 \mathrm{me} 1 / 2$ when complexed to the androgen receptor (Metzger et al. 2005), and other LSD1 variants have shown different
A

LSD1/KDM1 family:
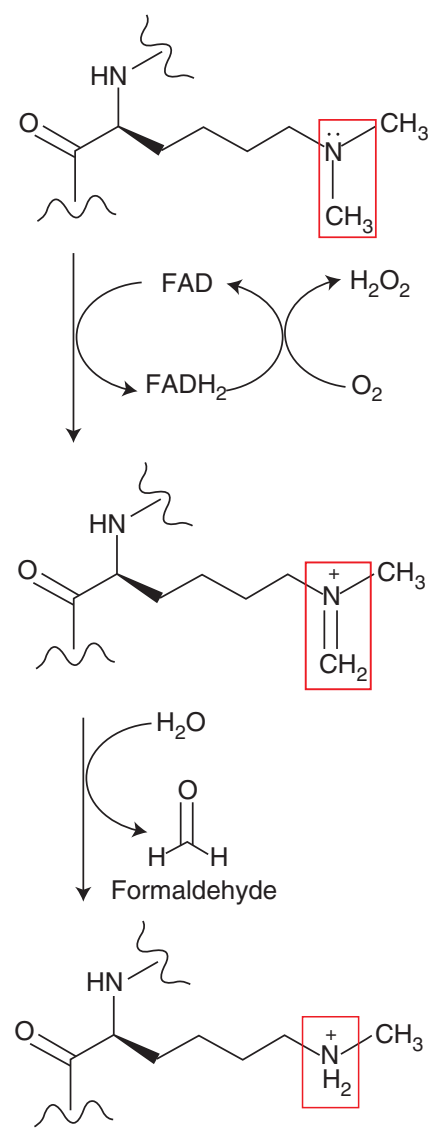

B JmjC family:

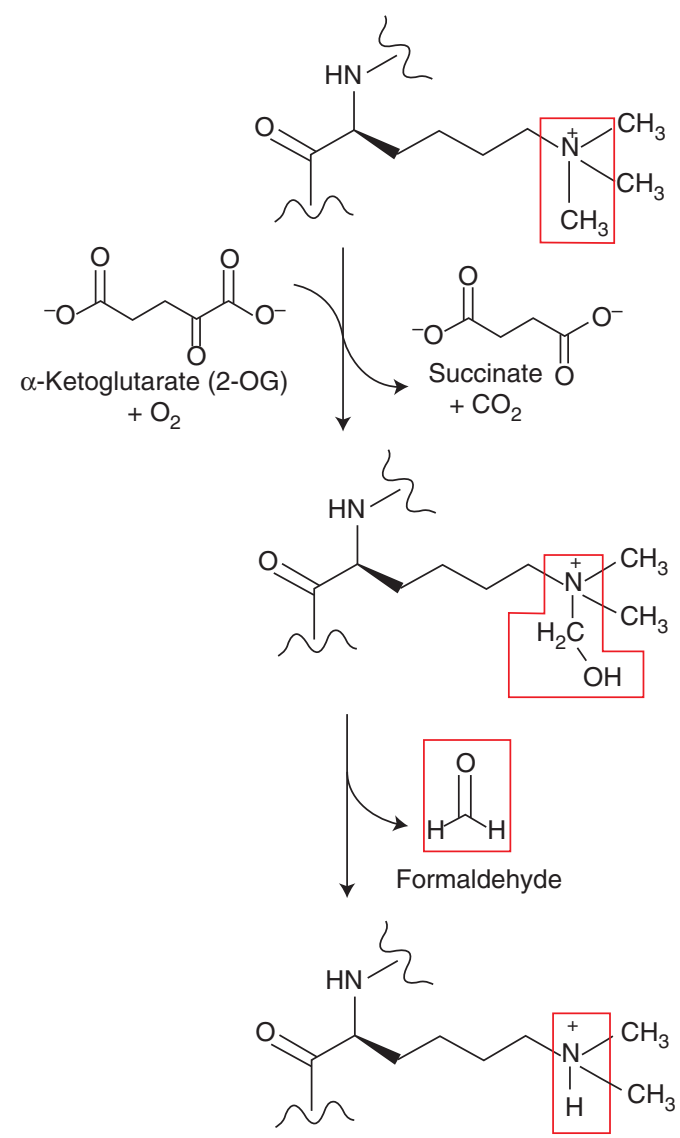

Figure 1. Reaction mechanism of demethylation. Demethylation catalyzed by $(A)$ LSD1/ KDM1-family and $(B)$ JmjC-family enzymes. 
Histone Lysine Demethylase Inhibitors

substrate specificities (Laurent et al. 2015; Wang et al. 2015a). Later, multiple groups discovered additional histone demethylases with various substrate requirements (both in terms of lysine residues as well as extent of methylation), revealing the dynamic nature of multiple types of histone methylations. With the exception of LSD2, a close homolog of LSD1 (Karytinos et al. 2009; Fang et al. 2010), the other demethylases fall into the Jumonji C (JmjC) class, which uses Fe(II) and 2-oxoglutarate (2-OG, or $\alpha$-ketoglutarate) as cofactors to hydroxylate the methyl groups via a free-radical mechanism (Fig. 1B), which is then released as formaldehyde (Tsukada et al. 2006). Importantly, this reaction mechanism allows the reversal of trimethylations (Cloos et al. 2006; Klose et al. 2006; Whetstine et al. 2006), which LSD1 and LSD2 cannot catalyze. The discoveries of these enzymes highlight the specific and dynamic regulation of methylation at various histone lysine residues.

\section{ABERRANT HISTONE REGULATION IN CANCER}

Misregulation of lysine demethylases is frequently observed in cancer, and the diverse natures of the regulatory defects indicate that cellular homeostasis requires a precise balance of histone methylation and demethylation. Mutations or translocations of genes encoding demethylases are relatively infrequent, but variations in the expression levels of demethylases are more common (Chen et al. 2014). Because the combination of histone modifications with other regulatory processes influences the overall biological outcomes, the misregulation of demethylases in tumors can result in different consequences depending on the tissue of origin, the presence of other mutations, and the activities of other gene expression networks. For example, LSD1 is down-regulated in some breast cancers (Wang et al. 2009), but up-regulated in many other solid tumors and leukemias (Hayami et al. 2011; Schildhaus et al. 2011). A single type of cancer can show misregulation of different demethylases, such as up-regulation of KDM5C (Wang et al. 2015c), KDM5B (Yamane et al. 2007), KDM4A, or KDM4B (Berry et al.
2012) in breast cancers. Although co-occurring mutations in chromatin regulators have been documented in bladder cancer (Gui et al. 2011), the extent to which such events occur has not been comprehensively analyzed, leaving open the possibility that defects in multiple chromatin regulators may be operative in some cancers. Although current cancer genome sequencing efforts have not found frequent mutations and translocations of histone demethylases in cancers, there are a few notable examples. KDM6A (UTX), an H3K27me2/3 demethylase (Agger et al. 2007; Lan et al. 2007), is often truncated or mutated in a wide range of cancers, including cancers of the breast, pancreas, lung, and kidney and in leukemias (van Haaften et al. 2009; Dalgliesh et al. 2010). Additionally, a fusion of the $\mathrm{H} 3 \mathrm{~K} 4 \mathrm{me} 2 / 3$ demethylase KDM5A (JARID1A) to the nuclear pore component Nup98 was described in one acute myeloid leukemia (AML) case (van Zutven et al. 2006), and this fusion caused leukemias when expressed in mice (Gough et al. 2014). Thus, changes in expression levels, mutations, or translocations of histone demethylase genes can all contribute to carcinogenesis.

Although the precise effects of the misregulation of histone demethylases have not been determined for many cancers, the carcinogenic potential of these events appears to rest on direct or indirect regulation of tumor suppressors or oncogenes. Increased LSD1 expression, induced by expressing a genetic MLL-AF9 fusion in murine leukemia model, promoted transcription of MYC and the associated "core module" of embryonic stem cell (ESC) genes (Harris et al. 2012), leading to excessive proliferation and a loss of normal differentiation. In AML, LSD1 represses differentiation markers such as E-cadherin (Murray-Stewart et al. 2014). Consistently, chemical or genetic inhibition of LSD1 results in differentiation of leukemia cells in vitro (Schenk et al. 2012), and LSD1 has been suggested to regulate cancer stem cells (Harris et al. 2012). Loss of LSD1 expression in some breast cancers up-regulates transforming growth factor $\beta$ (TGF- $\beta$ ), promoting cellular invasion (Wang et al. 2009), whereas overexpression of KDM5B (PLU-1) represses genes that promote differen- 
A. Jambhekar et al.

tiation and maintenance of genome integrity, such as CAV-1 and BRCA-1 (Yamane et al. 2007). In prostate cancer, KDM4B overexpression promotes cell proliferation by targeting cell cycle regulators such as PLKand Aurora kinase A (Duan et al. 2015). KDM5A (JARID1A) promotes the maintenance of a drug-resistant state in a subset of cancer cells, although the essential KDM5A targets responsible for this phenotype have yet to be identified (Sharma et al. 2010). These studies highlight the context-dependent effects of demethylases in cancer, and suggest that re-establishing the balance of methylation levels could be an effective therapeutic strategy.

Given the therapeutic potential of targeting histone methylation in cancer and other diseases, many research groups are pursuing the development of demethylase inhibitors. Because the catalytic amine oxidase domain of LSD1 is homologous to that of MAOs, the first drugs developed against LSD1 were based on MAO inhibitors (MAOIs), which suffered from a lack of specificity for LSD1 (Lee et al. 2006). Drug development for the JmjC class of demethylases has focused on optimizing mimics of the 2-OG cofactor (Chen et al. 2007) or developing inhibitors that interfere with metal binding (e.g., Sekirnik et al. 2009). Additionally, focused screens of natural compounds (Willmann et al. 2012; Wu et al. 2012) or other classes of molecules such as polyphenols (Abdulla et al. 2013) have yielded effective histone demethylase inhibitors. Over the years, a plethora of compounds targeting histone lysine demethylases has been developed; we will focus on inhibitors reported in the academic literature to have shown activity in cellular or animal model studies of cancer, as these compounds show the most potential for development into therapeutics.

\section{LSD1/KDM1A}

LSD1 is a flavin-dependent monoamine oxidase homolog that demethylates $\mathrm{H} 3 \mathrm{~K} 4 \mathrm{me} 2$ in vitro and in vivo (Shi et al. 2004), and can demethylate $\mathrm{H} 3 \mathrm{~K} 9 \mathrm{me} 2$ in vivo when associated with nuclear hormone receptor complexes (Metzger et al. 2005; Garcia-Bassets et al. 2007; Perillo et al. 2008). LSD1-dependent demethylation is conducted by the catalytic amine oxidase domain, in conjunction with a SWIRM domain that mediates LSD1 stability (Chen et al. 2006; Stavropoulos et al. 2006) and histone recognition (Stavropoulos et al. 2006), and a Tower domain that interacts with the transcriptional repressor CoREST (Chen et al. 2006), which is important for LSD1 to access nucleosomal substrates (Lee et al. 2005; Shi et al. 2005). LSD1 can both activate and repress transcription (Wang et al. 2007), depending on the surrounding chromatin landscape (Perillo et al. 2008), its association with cofactors (Garcia-Bassets et al. 2007), and whether it targets $\mathrm{H} 3 \mathrm{~K} 4 \mathrm{me} 2$ (Martin and Zhang 2005) or H3K9me2 (Barski et al. 2007). The specificity of LSD1 for $\mathrm{H} 3 \mathrm{~K} 4 \mathrm{me} 2$ over $\mathrm{H} 3 \mathrm{~K} 9 \mathrm{me} 2$ is in part determined by the LSD1 splice isoform being expressed (Laurent et al. 2015; Wada et al. 2015; Wang et al. 2015a). We found that the inclusion of an eight-amino-acid exon switched its specificity from $\mathrm{H} 3 \mathrm{~K} 4 \mathrm{me} 2$ to H3K9me2 (Laurent et al. 2015), and others have reported substrate preferences of $\mathrm{H} 3 \mathrm{~K} 9 \mathrm{me} 2$ (Wada et al. 2015) or H4K20me1/2 for different splice variants of LSD1 (Wang et al. 2015a). LSD1 is typically overexpressed in cancers (Hayami et al. 2011; Schildhaus et al. 2011), and even though the critical targets that promote carcinogenesis vary between cancer types, LSD1 inhibitors have been actively pursued. LSD1 inhibitors fall into four major classes: irreversible derivatives of the monoamine oxidase inhibitors (Fig. 2), reversible polyamine or peptide inhibitors, rationally designed fusions of active molecules, and novel compounds not known to inhibit MAOIs (Fig. 3). These classes are discussed in detail below (Table 1; Figs. 2 and 3).

\section{IRREVERSIBLE LSD1 INHIBITORS}

The earliest inhibitors tested against LSD1 were irreversible MAOIs, selected based on the homology of the catalytic domain of LSD1 with that of the monoamine oxidases (MAOs, of which there are two, MAO-A and MAO-B). Pargyline (Fig. 2), which forms a covalent adduct with FAD (Oreland et al. 1973), was effective in cell culture (Metzger et al. 2005; Lv et al. 2012) and tumor xenografts models (Cortez et al. 

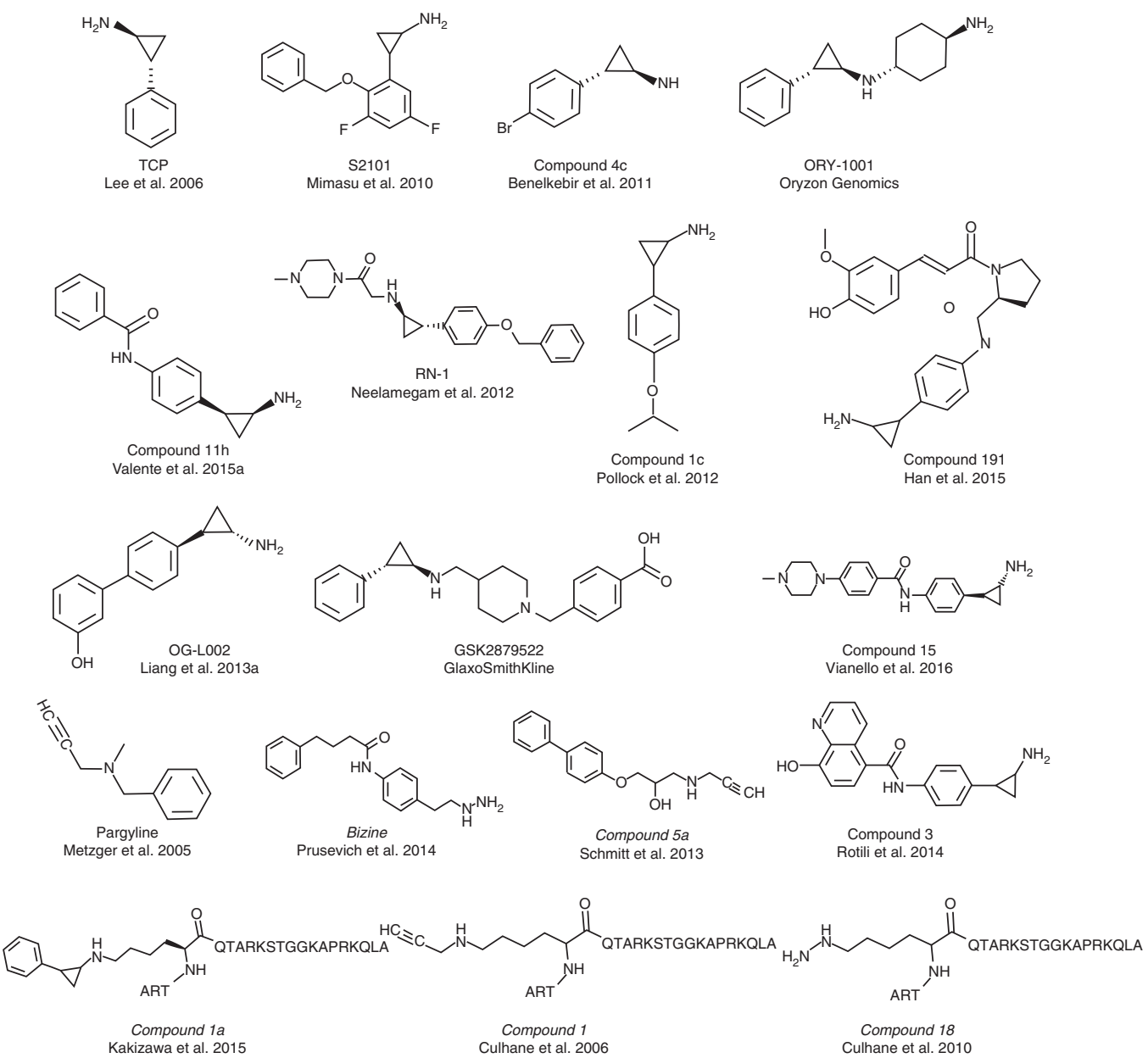

Figure 2. Chemical structures of irreversible LSD1 inhibitors, and references describing their development or use. Compounds listed in italics have not shown cytotoxic activity.

2012; Sareddy et al. 2013; Wang et al. 2015b) on its own, or when used in combination therapies (Rose et al. 2008; Huang et al. 2012; Vasilatos et al. 2013). However, pargyline showed low potency for inhibiting LSD1 in vitro (Schmidt and McCafferty 2007) and in vivo (Kauffman et al. 2011), suggesting that certain transcriptional or chromatin regulatory events might be sensitive to incomplete inhibition of LSD1, or the cellular effects of pargyline may arise from off-target interactions. In contrast, bizine (Fig. 2), a derivative of the irreversible MAOI phenelzine, promisingly showed specificity for LSD1 over MAO-A and MAO-B, but has not been extensively tested in vivo (Prusevich et al. 2014). A third irrevers- ible inhibitor, tranylcypromine (TCP) (Fig. 2), long used for treating psychiatric diseases (Agin 1960), also efficiently inhibited LSD1 (Lee et al. 2006) by forming a covalent adduct with the FAD cofactor (Schmidt and McCafferty 2007; Yang et al. 2007). Despite a lack of specificity for LSD1 over other MAOs, TCP inhibited growth in several cell-culture-based models of cancer (Ding et al. 2013; Ferrari-Amorotti et al. 2013), mouse xenograft models of breast cancer and oral squamous cell carcinoma (Ferrari-Amorotti et al. 2014; Wang et al. 2016), and a genetic model of MLL-AF9-driven driven acute myeloid leukemia (AML) (Harris et al. 2012). Additionally, TCP has been effective in 
A. Jambhekar et al.
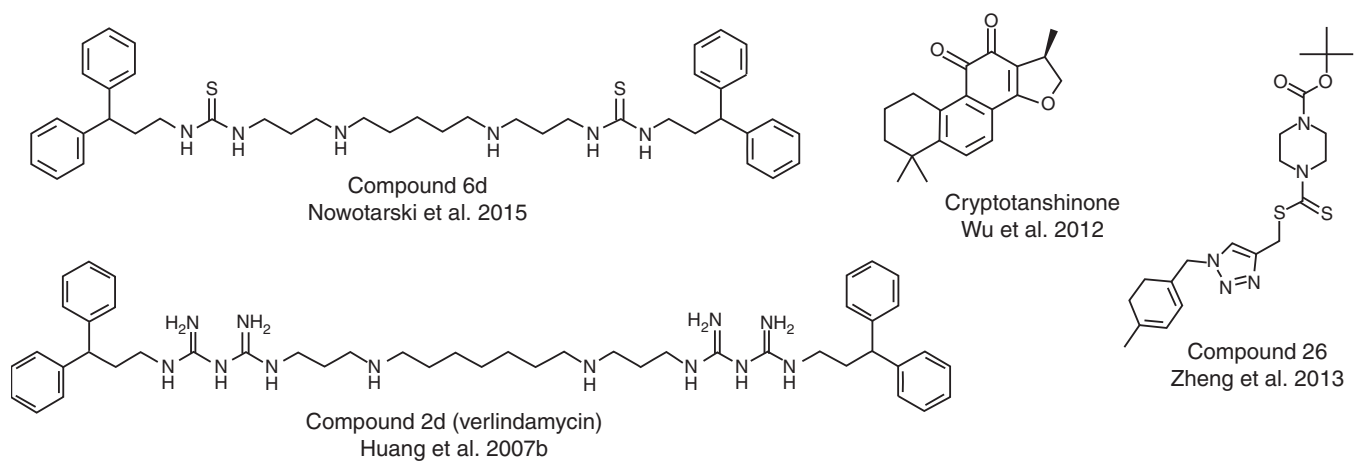
Wu et al. 2012

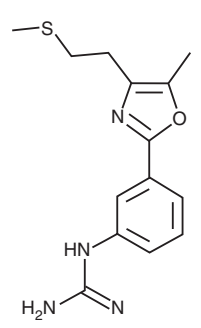

Compound 9a Dulla et al. 2013

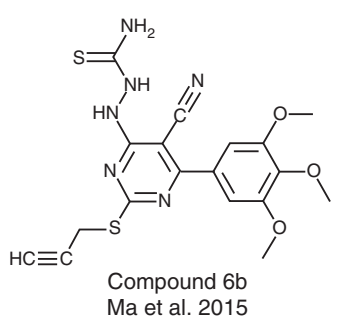

Ma et al. 2015

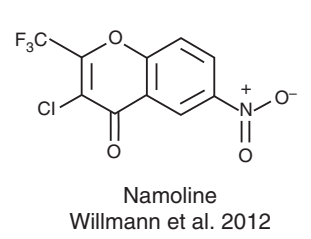

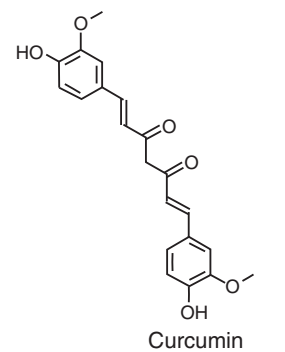

Abdulla et al. 2013
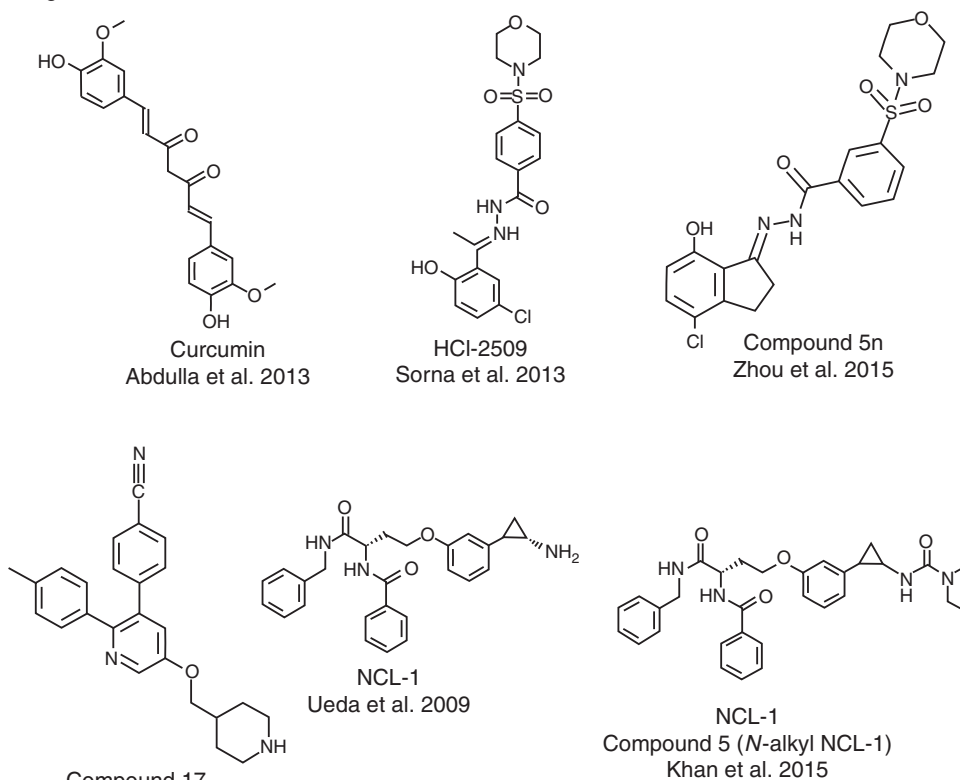

Compound 17

Wu et al. 2016

Figure 3. Chemical structures of reversible LSD1 inhibitors, and references describing their development or use. Letters in large font denote single-letter amino acid codes. Compounds listed in italics have not shown cytotoxic activity.

combination therapy approaches (Singh et al. 2011; Schenk et al. 2012), notably promoting AML differentiation in combination with alltrans retinoic acid (ATRA) (Schenk et al. 2012). Two clinical trials are underway to evaluate this combination therapy in AML and myelodysplastic syndrome (MDS). The success of combination therapy approaches indicates that this strategy may be a viable alternative to the development of highly specific compounds, as it can allow each drug to be used at a lower dose, thus minimizing off-target effects.

Despite the successes of TCP, multiple groups have attempted to increase its specificity for LSD1, resulting in compounds with small (e.g., compounds 4c [Benelkebir et al. 2011), 
Table 1. LSD1 inhibitors displaying cytotoxic effects

\begin{tabular}{|c|c|c|c|c|c|}
\hline \multirow[b]{2}{*}{ Name } & \multicolumn{5}{|c|}{ In vitro } \\
\hline & $\begin{array}{l}\text { Where first } \\
\text { described }\end{array}$ & Inhibits & Does not inhibit & $\begin{array}{l}\text { Mouse tumor } \\
\text { studies }\end{array}$ & $\begin{array}{l}\text { Additional } \\
\text { references }\end{array}$ \\
\hline $\mathbf{T C P}^{*}$ & Lee et al. 2006 & $\begin{array}{l}\text { LSD1, MAO-A, } \\
\text { MAO-B }\end{array}$ & & $\begin{array}{l}\text { Leukemia and } \\
\text { oral } \\
\text { squamous } \\
\text { cell } \\
\text { carcinoma } \\
\text { xenografts }\end{array}$ & $\begin{array}{l}\text { Harris et al. } \\
\text { 2012; Ferrari- } \\
\text { Amorotti } \\
\text { et al. 2014; } \\
\text { Wang et al. } \\
2016\end{array}$ \\
\hline ORY-1001* & Oryzon Genomics & LSD1 & & & \\
\hline GSK2879553* & GlaxoSmithKline & LSD1 & & & \\
\hline Bizine & $\begin{array}{l}\text { Prusevich et al. } \\
2014\end{array}$ & LSD1 & & & \\
\hline Compound 1 & Culhane et al. 2006 & LSD1 & & & \\
\hline Compound 1a & $\begin{array}{l}\text { Kakizawa et al. } \\
2015\end{array}$ & LSD1 & & & \\
\hline Compound 1c & Pollock et al. 2012 & LSD1 & & & \\
\hline Compound 3 & Rotili et al. 2014 & $\begin{array}{l}\text { LSD1, KDM2, } \\
\text { KDM3, } \\
\text { KDM4C, } \\
\text { KDM4E, } \\
\text { KDM5, } \\
\text { KDM6, PHD2 }\end{array}$ & $\begin{array}{l}\text { MAO-A, } \\
\text { MAO-B, FIH }\end{array}$ & & \\
\hline Compound 4c & $\begin{array}{l}\text { Benelkebir et al. } \\
2011\end{array}$ & LSD1 & & & \\
\hline Compound $5 a$ & Schmitt et al. 2013 & $\begin{array}{l}\text { LSD1, MAO-A, } \\
\text { MAO-B }\end{array}$ & & & \\
\hline Compound $11 \mathrm{~h}$ & Valente et al. $2015 \mathrm{a}$ & LSD1, MAO-A & MAO-B & & Binda et al. 2010 \\
\hline Compound 15 & Vianello et al. 2016 & LSD1 & $\begin{array}{l}\text { LSD2, MAO-A, } \\
\text { MAO-B }\end{array}$ & $\begin{array}{l}\text { Genetic APL } \\
\text { mouse } \\
\text { model }\end{array}$ & Binda et al. 2010 \\
\hline Compound 18 & Culhane et al. 2010 & LSD1 & & & \\
\hline Compound 191 & Han et al. 2015 & LSD1 & MAO-A, MAO-B & & \\
\hline OG-L002 & Liang et al. 2013a & LSD1 & MAO-A, MAO-B & & \\
\hline Pargyline & Metzger et al. 2005 & $\begin{array}{l}\text { LSD1, MAO-A, } \\
\text { MAO-B }\end{array}$ & & $\begin{array}{c}\text { Breast cancer } \\
\text { and glioma } \\
\text { xenograft }\end{array}$ & $\begin{array}{l}\text { Huang et al. } \\
\text { 2012; Sareddy } \\
\text { et al. } 2013\end{array}$ \\
\hline $\mathrm{RN}-1$ & $\begin{array}{l}\text { Neelamegam et al. } \\
2012\end{array}$ & $\begin{array}{l}\text { LSD1, MAO-A } \\
\text { (weakly) }\end{array}$ & MAO-B & & $\begin{array}{l}\text { Konovalov and } \\
\text { Garcia- } \\
\text { Bassets } 2013\end{array}$ \\
\hline S2101 & Mimasu et al. 2010 & LSD1 & MAO-A, MAO-B & & $\begin{array}{l}\text { Konovalov and } \\
\text { Garcia- } \\
\text { Bassets 2013; } \\
\text { Suva et al. } \\
2014\end{array}$ \\
\hline CBB1007 & Wang et al. 2011 & LSD1 & & & \\
\hline $\begin{array}{l}\text { Compound } 2 \mathrm{~d} \\
\text { (verlindamycin) }\end{array}$ & Huang et al. 2007b & LSD1 & & $\begin{array}{l}\text { AML and colon } \\
\text { cancer } \\
\text { xenograft }\end{array}$ & $\begin{array}{l}\text { Huang et al. } \\
\text { 2009; Schenk } \\
\text { et al. } 2012\end{array}$ \\
\hline
\end{tabular}


A. Jambhekar et al.

Table 1. Continued

\begin{tabular}{|c|c|c|c|c|c|}
\hline \multirow[b]{2}{*}{ Name } & \multicolumn{5}{|c|}{ In vitro } \\
\hline & $\begin{array}{l}\text { Where first } \\
\text { described }\end{array}$ & Inhibits & Does not inhibit & $\begin{array}{l}\text { Mouse tumor } \\
\text { studies }\end{array}$ & $\begin{array}{l}\text { Additional } \\
\text { references }\end{array}$ \\
\hline $\begin{array}{c}\text { Compound 5n } \\
\text { (HCI-2509 } \\
\text { derivative) }\end{array}$ & Zhou et al. 2015 & LSD1 & & & \\
\hline Compound 6b & Ma et al. 2015 & LSD1 & & $\begin{array}{c}\text { Gastric cancer } \\
\text { xenograft }\end{array}$ & \\
\hline Compound $6 \mathrm{~d}$ & $\begin{array}{l}\text { Nowotarski et al. } \\
2015\end{array}$ & LSD1 & MAO-A, MAO-B & & \\
\hline Compound 9a & Dulla et al. 2013 & LSD1 & & & \\
\hline Compound $16 q$ & Hitchin et al. 2013 & LSD1 & MAO-A & & \\
\hline Compound 17 & Wu et al. 2016 & LSD1, MAO-B & MAO-A & & \\
\hline Compound 26 & Zheng et al. 2013 & LSD1 & MAO-A, MAO-B & & \\
\hline Cryptotanshinone & Wu et al. 2012 & LSD1 & & & \\
\hline Curcumin & Abdulla et al. 2013 & LSD1 & & & \\
\hline HCI-2509 & Sorna et al. 2013 & LSD1 & MAO-A, MAO-B & $\begin{array}{l}\text { Ewing's } \\
\text { sarcoma } \\
\text { xenograft }\end{array}$ & $\begin{array}{l}\text { Fiskus et al. } \\
\text { 2014; Sankar } \\
\text { et al. 2014; } \\
\text { Theisen et al. } \\
\text { 2014; Zhou } \\
\text { et al. } 2015\end{array}$ \\
\hline Namoline & $\begin{array}{l}\text { Willmann et al. } \\
2012\end{array}$ & LSD1 & MAO-A, MAO-B & $\begin{array}{l}\text { Prostate cancer } \\
\text { xenograft }\end{array}$ & \\
\hline NCL-1 & $\begin{array}{l}\text { Ogasawara et al. } \\
2011\end{array}$ & LSD1 & MAO-A, MAO-B & $\begin{array}{l}\text { Prostate cancer } \\
\text { xenograft }\end{array}$ & $\begin{array}{l}\text { Ueda et al. 2009; } \\
\text { Cortez et al. } \\
\text { 2012; Sareddy } \\
\text { et al. 2013; } \\
\text { Etani et al. } \\
\text { 2015; } \\
\text { Hoshino et al. } \\
2016\end{array}$ \\
\hline SNAIL peptide & $\begin{array}{l}\text { Tortorici et al. } \\
2013\end{array}$ & LSD1 & & & \\
\hline
\end{tabular}

Note: Inhibitors marked with an asterisk are in clinical trials, and those in bold are irreversible. Italics indicate that the compounds have not been tested in vivo. In cases in which a single report described multiple, related compounds, only the most potent and/or selective one is listed. Specificity is reported based on the original authors' interpretation of their data; additional information can be found in the cited references.

APL, acute promyelocytic leukemia; AML, acute myeloid leukemia.

1c (Pollock et al. 2012), and OG-L002 (Liang et al. 2013a]) or large (e.g., compounds $11 \mathrm{~h}$ [Binda et al. 2010; Valente et al. 2015a,b], 15 [Binda et al. 2010; Vianello et al. 2016], and 17 [Wu et al. 2016]) substitutions at the para position, and/or at the primary amine (e.g., RN-1 [Neelamegam et al. 2012] and compound 17 [Wu et al. 2016]) (Figs. 2 and 3). These compounds effectively inhibited cancer cell growth in culture (Binda et al. 2010; Benelkebir et al. 2011; Pollock et al. 2012; Konovalov and GarciaBassets 2013; Valente et al. 2015a,b; Wu et al. 2016). Notably, compound 17 (Fig. 3) (Wu et al. 2016) functioned as a competitor of the methylated $\mathrm{H} 3$ peptide, having lost its ability to form a covalent bond with FAD during the derivatization process (Wu et al. 2016). Two compounds (13b and 14e) developed as specific 
Histone Lysine Demethylase Inhibitors

LSD1 inhibitors (Binda et al. 2010) were further derivatized and optimized with respect to stereochemistry, yielding compounds $11 \mathrm{~h}$ (Valente et al. 2015a) and 15 (Fig. 2) (Vianello et al. 2016). The latter compound increased survival in an acute promyelocytic leukemia mouse model when delivered orally as a single agent (Vianello et al. 2016). Guided by predictions of the docking of TCP derivatives into the active site of LSD1, Mimasu et al. (2010) capitalized on the slightly larger catalytic cleft of LSD1 to develop an analog (S2101) (Fig. 2) that inhibited LSD1 at least 50-fold more effectively than it did either MAO, and reduced the viability of glioma (Suva et al. 2014) and ovarian cancer cells (Konovalov and Garcia-Bassets 2013) in culture. Although some of these studies systematically compared the activity of TCP or its derivatives against LSD1 and MAOs in vitro (Binda et al. 2010; Mimasu et al. 2010; Neelamegam et al. 2012; Valente et al. 2015a,b; Wu et al. 2016), it is not clear whether any in vivo effects arise from a combination of LSD1 inactivation and inhibition of other enzymes. In fact, RN-1 (Fig. 2) affects memory in mice through mechanisms that are not fully understood. Depletion of a neuronal LSD1 isoform (Wang et al. 2015a) was reported to impair learning and memory, and inhibition of other MAOs is also expected to inhibit memory storage (Neelamegam et al. 2012) by affecting the expression of glucocorticoid receptors (Heydendael and Jacobson 2009), which play key roles in memory consolidation (Quirarte et al. 1997). Other indirect effects that could contribute to the memory phenotypes caused by $\mathrm{RN}-1$ include impaired production of insulin on MAO inhibition (Feldman and Chapman 1975). Thus, the effects of $\mathrm{RN}-1$ could arise from LSD1 inhibition, or off-target effects on other enzymes, including the two other MAOs (Shih et al. 2011). Whether any of the TCP derivatives also reacts with any other FAD-utilizing enzymes - of which there are more than 75 , participating in processes such as sugar catabolism, electron transport, and lipid metabolism (Lienhart et al. 2013) — has not been thoroughly tested, and would be important to determine before application in the clinic. Systematic compari- sons of the effects of TCP analog treatment, with or without additional LSD1 inhibition, would yield insight into the extent to which off-target effects contribute to in vivo phenotypes. In general, bulky substituents that capitalize on the larger binding pocket of LSD1 compared with the other MAOs seem to confer some degree of specificity. Notably, the structureguided designs of Mimasu et al. (2010) achieved specificity for LSD1 over the MAOs in vitro, suggesting that further development of specific TCP derivatives could be achieved by rational design. Given the variety of TCP derivatives reported in the literature, a systematic comparison of their chemical features may yield insight into the types and locations of substitutions that confer specificity over each MAO, aiding further rational design attempts.

\section{REVERSIBLE INHIBITORS}

Reversible poly- and monoamine oxidase inhibitor scaffolds — such as polyamines (Bianchi et al. 2006) and pyrimidines (George et al. 1971) — have also been used to generate LSD1 inhibitors. Derivatization of these scaffolds (Huang et al. 2007b; Ma et al. 2015; Nowotarski et al. 2015) yielded molecules (2d, 6b, and 6d, respectively) (Fig. 3) that displayed improved specificity for LSD1 in vitro and inhibited the growth of several types of cancer cells in culture. A pyrimidine thiourea-containing compound (6b) potently inhibited LSD1, and repressed the growth of gastric cancer cell lines in culture and in mouse xenografts with no overt side effects (Ma et al. 2015) (Fig. 3). To improve specificity, peptide-based molecules have also been used, which take advantage of the specific binding of LSD1 to its substrates or other interaction partners. A 6-mer peptide derived from SNAIL (Fig. 3), a competitive inhibitor of LSD1 in vivo (Baron et al. 2011), showed efficacy in vitro (Tortorici et al. 2013). In a second study, CBB1003 and its methyl ester CBB1007 (Fig. 3 ), both small molecules designed to mimic the $\mathrm{H} 3$ substrate, reduced the proliferation of multiple cancers derived from pluripotent cells (e.g., embryonic carcinomas) in culture (Wang et al. 2011). Few studies have compared the ef- 
A. Jambhekar et al.

fects of reversible and irreversible inhibitors in parallel on cell or tumor growth. In one case, polyamine compound $2 \mathrm{~d}$ (verlindamycin) (Fig. 3) (Huang et al. 2009) proved less potent than TCP at inducing AML differentiation in combination with ATRA; but on its own, $2 \mathrm{~d}$ was surprisingly more effective (Schenk et al. 2012). These results suggest that polyamines and TCP may affect different aspects of LSD1 function in addition to its catalytic activity (e.g., its assembly into complexes or its localization to H3K4me2 sites). In fact, both TCP and pargyline were shown to reduce LSD1 protein levels, in addition to inactivating the enzyme (Wang et al. 2016). A comparative assessment of the effects of reversible and irreversible LSD1 inhibitors on its expression levels, localization, and association with binding partners could reveal additional mechanisms of LSD1 inhibition, and novel strategies for developing specific inhibitors. Just as unique applications for irreversible and reversible cyclooxygenases inhibitors have been established (for suppressing clotting [Schror 1997] and inflammation [Simon and Mills 1980], respectively), further studies may reveal similar nonredundant uses for irreversible and reversible LSD1 inhibitors.

\section{BIFUNCTIONAL LSD1 INHIBITORS}

Several groups have designed inhibitors by fusing two or more features of known LSD1 inhibitors into a single molecule, as multifunctional drugs can improve the efficacy and/or reduce off-target effects of individual drugs (Mai et al. 2008). Histone H3 peptides (compounds 1 [Culhane et al. 2006], 18 [Culhane et al. 2010], and 1a [Kakizawa et al. 2015]) (Fig. 2), or peptide mimics, fused at the $\varepsilon$-amine of $\mathrm{K} 4$ to cyclic groups (mimicking the cyclopropane group of TCP) (Ueda et al. 2009) or propargylamines (mimicking pargyline) (e.g., compound 5a [Schmitt et al. 2013]), inhibited LSD1 in vitro. The peptide mimic NCL-1 (Fig. 3) (Ueda et al. 2009; Ogasawara et al. 2011) inhibited the growth of multiple types of cancer cells in culture (Cortez et al. 2012; Sareddy et al. 2013; Hoshino et al. 2016), as well as prostate cancer xenografts in mice with minimal toxicity (Etani et al. 2015). Surprisingly, an $N$-alkylated derivative (compound 5), fusing features of ORY1001 to NCL-1, displayed improved potency only in vitro, but not in vivo (Fig. 3) (Khan et al. 2015). A separate study combined elements of TCP, polyamine analog inhibitors, and peptide inhibitors to generate compound 9a, which suppressed breast cancer cell proliferation in culture (Fig. 3) (Dulla et al. 2013).

Two groups generated bifunctional inhibitors by combining MAOIs with compounds displaying anti-proliferative activities-either hydroxylcinnamic acid (compound 191 [Han et al. 2015]) (Fig. 2) or carbamates (compound 26 [Zheng et al. 2013]) (Fig. 3) - and both sets suppressed proliferation in a variety of cancer lines in culture. Based on the finding that LSD1 and the JmjC demethylase KDM4 colocalize at androgen-dependent promoters (Wissmann et al. 2007), Rotili and colleagues fused TCP to JmjC inhibitors bipyridine (compound 2) or hydroxyquinoline (compound 3). Both fusions effectively inhibited LSD1 and all tested JmjC demethylases with minimal effects on MAO-B (compound 2) or both MAO-A and MAO-B (compound 3), and preferentially suppressed the growth of prostate cancer lines over a noncancerous cell line in culture (Rotili et al. 2014). Intriguingly, the fusion compounds induced apoptosis more effectively than did a combination of the two inhibitors alone at the same concentration (Rotili et al. 2014) (Fig. 2). Like combination therapies, these strategies aimed to maximize potency and specificity combinatorially, although the ORY-1001NCL-1 fusion (Khan et al. 2015) shows that this approach is not foolproof.

Although these bifunctional compounds have shown remarkable success, their mechanisms of action remain unresolved. The compounds reported by Rotili et al. (2014) raise the question of how the demethylase targets are arranged spatially in the cell, and whether their geometries (in addition to their catalytic activities) are important for their function. For example, do the fusion inhibitors trap the demethylases in a configuration that is incompatible with any catalytic-independent function(s) (e.g., recruitment of additional regulators), in a 
way that the individual inhibitors cannot accomplish? Biochemical and structural studies of the demethylase complexes with each inhibitor would be particularly informative in understanding the functions of the inhibitors and their demethylase targets in cells. The fusion compounds with antiproliferatives raise additional questions, such as the identities of the molecules targeted by these compounds. The targets of the antiproliferatives remain unknown, and it is likely that each compound has multiple targets, given that a fusion of hydroxylcinnamic acid to a Ras inhibitor increased cytotoxicity (Ling et al. 2014), despite the fact that Ras and LSD1 localize to different cellular compartments. These results suggest that hydroxylcinnamic acid could have both plasma membrane-localized and nuclear targets, or it may simply increase the permeability of its fusion partners into cells. Investigations into these areas will be important for understanding the mechanisms of action of these molecules, and will provide insight into the interaction of target molecules with each other, which could be used to inform further development of potent and specific inhibitors.

\section{OTHER INHIBITORS}

Several other groups have developed inhibitors specific to LSD1 by identifying compounds not already known to be MAOIs. Screening-based approaches identified aminothiazoles (compound 16q [Hitchin et al. 2013]) (Fig. 3), the natural compounds resveratrol and curcumin (Fig. 3) (Abdulla et al. 2013) (the latter also reported as a KDM4 inhibitor [Kim et al. 2014]); cryptotanshinone (Fig. 3) (Wu et al. 2012), and Namoline (Fig. 3) (Willmann et al. 2012) (a $\gamma$-pyrone that the same group had recently identified as an MAOI [Wetzel et al. 2010]), all of which (with the exception of aminothiazoles [Hitchin et al. 2013]) inhibited the growth of cancer cells in culture. Namoline showed some toxicity when tested in a prostate cancer xenograft (Willmann et al. 2012), highlighting a potential disadvantage of developing new inhibitors not previously used therapeutically. A virtual screen of compounds that can dock against LSD1 led to the rational design of a phenylethylidene-benzohydride (HCI2509, aka SP2509) (Fig. 3), which suppressed the growth of cancer cells in culture (Sorna et al. 2013), or in xenograft models of Ewing's sarcoma (Sankar et al. 2014) or endometrial cancer (Theisen et al. 2014) on its own, or AML xenografts in combination with the histone deacetylase (HDAC) inhibitor panobinostat (Fiskus et al. 2014). A sterically constrained derivative of HCI-2509, compound 5n, inhibited the growth of multiple cancer cell lines in culture more potently than HCI-2509 did (Fig. 3) (Zhou et al. 2015). Collectively, these studies suggest that compounds not already known to be MAOIs could have LSD1-specific inhibitory properties, and could be optimized for clinical use.

Despite the numerous classes of LSD1 inhibitors developed, few have been tested systematically for toxicity or efficacy in mouse models, and so far only three-TCP, ORY-1001, and GSK 2879552 (Fig. 2) (Maes et al. 2015)—are in clinical trials. Achieving specific inhibition of LSD1 over the other MAOs, and potentially other FAD-utilizing enzymes (in the case of irreversible inhibitors), remains a significant challenge, but the recent advances suggest the potential for further optimization. The in vivo and clinical applications of many of the LSD1 inhibitors described in the literature remain to be fulfilled, and could yield effective targeted therapeutics in the future.

\section{JmjC FAMILY}

The JmjC family of histone demethylases uses 2-OG and $\mathrm{Fe}(\mathrm{II})$ as cofactors to demethylate mono-, di-, and tri-methylated lysines. The substrate specificities of the enzymes vary, with some accepting multiple methylated lysines (e.g., KDM4A-C, which act on both H3K9 and H3K36 methylations [Woon et al. 2012; Labbe et al. 2013]), whereas others recognize only a single substrate (e.g., KDM2, which specifically demethylates H3K36me1-2 [Tsukada et al. 2006]). KDM4A, although it recognizes both H3K9 and H3K36 (Couture et al. 2007), shows a preference for trimethylated ly- 
A. Jambhekar et al.

sines (Klose et al. 2006; Whetstine et al. 2006), displaying more specificity for the methylation state than for the surrounding protein sequence. Like LSD1, JmjC enzymes display complex and context-dependent effects on gene expression. Overexpression of these enzymes in cancers is a common theme, whereas loss of function occurs less frequently (Hojfeldt et al. 2013) (with the exception of KDM6A, which is frequently mutated in cancers, as described above). In fact, KDM4C (GASC-1), had been initially found amplified in esophageal cancers (Yang et al. 2000), and was later implicated in medulloblastoma (Ehrbrecht et al. 2006) and breast cancer (Liu et al. 2009). As observed for LSD1, the KDM4 family exerts its effects in breast and prostate cancers by associating with nuclear hormone receptors (Yamane et al. 2007; Shi et al. 2011; Berry et al. 2012), leading to either overexpression of pro-proliferation genes or repression of tumor suppressors. Despite the similarities between enzymes of the same family, their roles in carcinogenesis appear distinct, as only some family members are found to be misregulated in each cancer type (Berry et al. 2012). Although the mechanisms underlying demethylase-promoted oncogenesis vary, demethylases represent good targets for drug therapies because of their widespread up-regulation across cancers, and in some cases showed roles in cancer stem cells (e.g., Nakamura et al. 2013). Many JmjC inhibitors have been identified, but as was the case for LSD1, achieving specificity has been challenging because the catalytic sites of these enzymes are not only homologous to each other, but also to other 2-OG dependent oxidases, such as PHD1 and FIH (Elkins et al. 2003). The major classes of inhibitors include cofactor mimics, substrate mimics, as well as compounds whose mechanism of action is poorly defined (Figs. 4 and 5; Table 2).

\section{INHIBITORS OF 2-OG-DEPENDENT ENZYMES}

As for LSD1, the first inhibitors tested for JmjC demethylase inhibition were those that had been developed for other related enzymes that use similar catalytic mechanisms. A number of researchers have exploited the 2-OG dependence of JmjC family demethylases to design inhibitors that interfere with 2-OG function. Because of their structural similarity to $N$ methyl and RNA demethylases, and to nucleic acid oxygenases, JmjC family demethylases have been targeted by inhibitors of 2-OG oxygenases, such as hydroxamate derivatives (Hamada et al. 2009; Itoh et al. 2015), $\mathrm{N}$-oxalyl amino acid derivatives (Rose et al. 2008, 2010; Hamada et al. 2009), pyridine dicarboxylates (Rose et al. 2008), and agents such as disulfiram (Sekirnik et al. 2009) (a drug used to treat alcoholism [Ellis and Dronsfield 2013]) that interfere with metal binding.

Two primary scaffolds for 2-OG-dependent enzyme inhibitors are $\mathrm{N}$-oxalylglycine (NOG) (Fig. 4), a 2-OG cofactor mimic (Baader et al. 1994) that binds $\mathrm{Fe}(\mathrm{II})$ but is resistant to superoxide attack (Elkins et al. 2003), and para 2,4 dicarboxylic acid (2,4-PDCA) (Fig. 4), another 2-OG mimic that occupies the 2-OG binding site but cannot complete catalysis (Tschank et al. 1987). NOG was first shown to inhibit KDM4C (Cloos et al. 2006), but showed little specificity for demethylases over other 2-OG oxygenases such as PHD2 and FIH (Hopkinson et al. 2013). Both rational (Rose et al. 2010) and screen-based (Mannironi et al. 2014) approaches identified NOG derivatives, of which the latter (compound 3195) (Fig. 5) weakly inhibited HeLa cell proliferation in culture (Mannironi et al. 2014) (the other, an N-oxalyl-D-tyrosine derivative, compound $7 f$ [Fig. 4], was not tested in vivo [Rose et al. 2010]). 2,4-PDCA (Fig. 4) also proved to be an effective inhibitor of JmjC demethylase activity in vitro (Rose et al. 2008; Mackeen et al. 2010; Hopkinson et al. 2013) and in vivo (Mackeen et al. 2010; Kristensen et al. 2012; Hopkinson et al. 2013), showing a preference for KDM4C over KDM6A (Kristensen et al. 2012), but generally inhibiting other 2-OG-dependent enzymes with equal potency (Hopkinson et al. 2013). An effective 2,4-PDCA derivative more specific for KDM4E than for PHD2 was generated by including a fluorophenyl substituted amine at the 3 position, compound 47 (Fig. 4) (Thalhammer et al. 2011), but this com- 


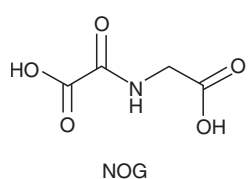
NOG
Cloos et al. 2006
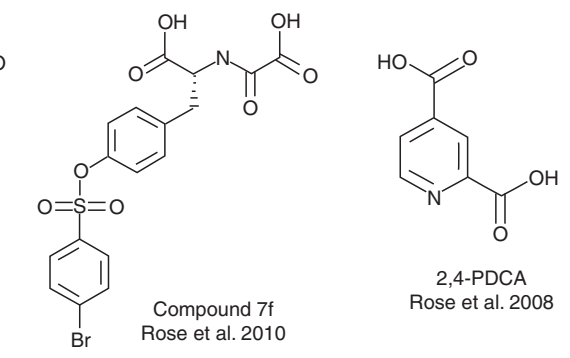
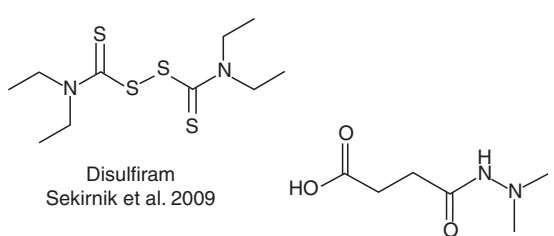
Daminozide
Rose et al. 2012
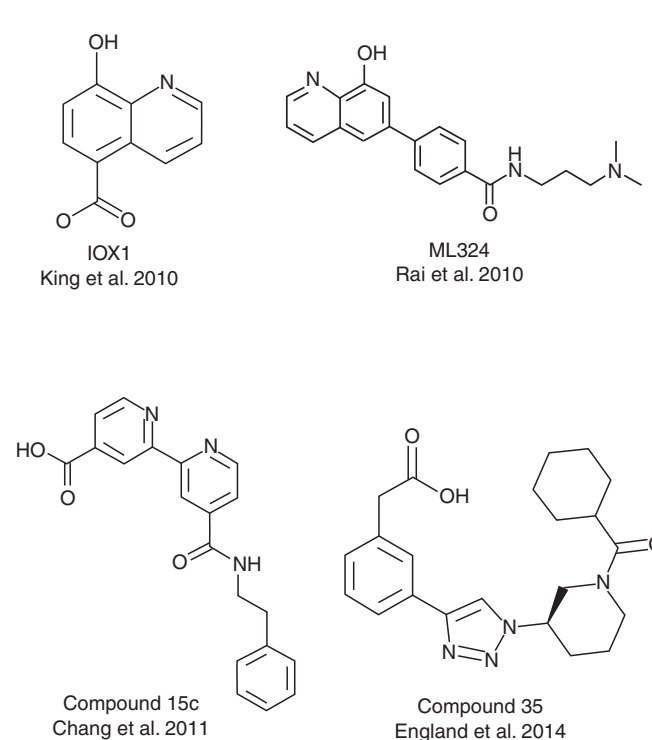

Chang et al. 2011

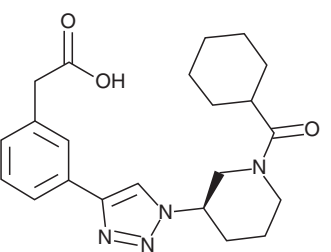

Compound 35 England et al. 2014
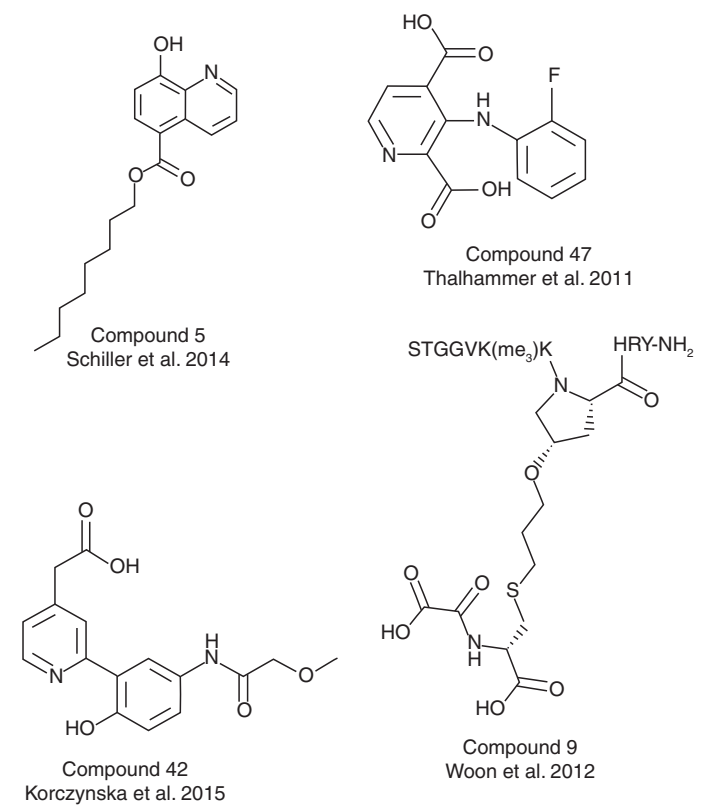

Compound 9 Woon et al. 2012

Figure 4. Chemical structures of select JmjC-family inhibitors that are effective in vitro, but have not shown JmjC-mediated cytotoxic activity. References describing their development or use are provided. Letters in large font denote single-letter amino acid codes.

pound has not been tested in vivo. Further development of the 2,4-PDCA scaffold could generate potent and selective inhibitors of histone demethylases, although a further challenge will be improving its cell permeability, as even the ester analogs require high concentrations in culture (Mackeen et al. 2010; Hopkinson et al. 2013) and have not been shown to inhibit cell proliferation. Systematic structural studies of the various JmjC members (as well as other 2OG-dependent enzymes) bound to 2-OG mimics, in the presence and absence of $2-\mathrm{OG}$, could reveal any differences in binding modes that can be exploited to develop inhibitors specific to individual family members.

\section{BIFUNCTIONAL JmjC INHIBITORS}

Other groups took the strategy of improving specificity of JmjC family inhibitors by generating bifunctional compounds, as was done for LSD1. Because the in vivo specificity of JmjC enzymes for their substrates stems from the sequence of the peptide surrounding the substrate lysine, bifunctional molecules relying on peptides (or their mimics) fused to 2-OG mimics have been synthesized (NCDM-32B [Hamada et al. 2009, 2010], methylstat [Luo et al. 2011], and compound 9 [Woon et al. 2012]) (Figs. 4 and 5). Surprisingly, this strategy led to unintended effects; an early attempt yielded an 
A. Jambhekar et al.
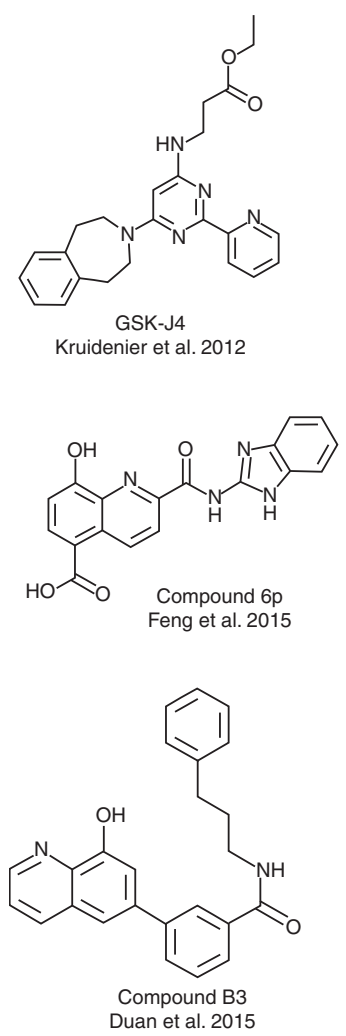
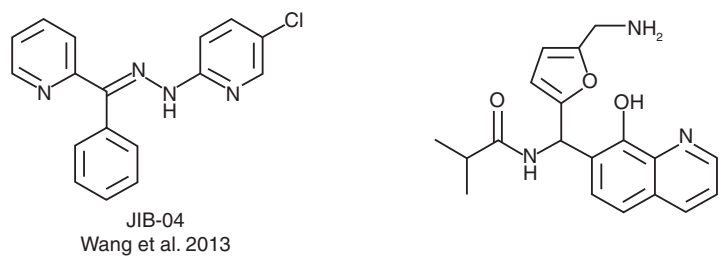

SD70 Jin et al. 2014<smiles>Cc1ccc(-n2sc3ccccc3c2=O)cc1</smiles><smiles>C[N+](=O)c1cc([N+](=O)[O-])c(/C=C/c2ccc(Cl)c(Cl)c2)cc1/C=C/c1ccc(Cl)c(Cl)c1</smiles>

Compound 4 Chu et al. 2014
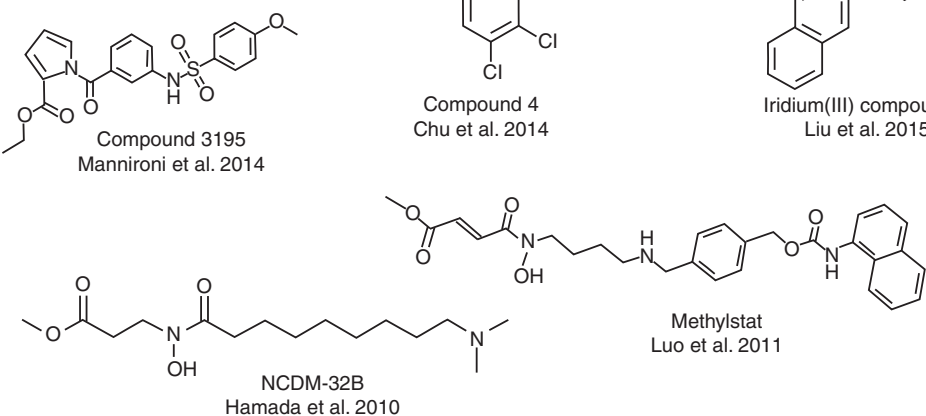
Luo et al. 2011

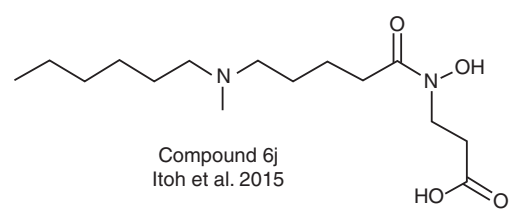

Figure 5. Chemical structures of JmjC-family inhibitors that have been shown to display cytotoxic activities. References describing their development or use are provided.

NOG derivative that inhibited enzyme(s) other than the one it was designed against (Hamada et al. 2009). Substitution of a hydroxamate at the amide linkage of NOG (which improved metal chelation, and was later used to develop the KDM5A inhibitor compound 6j [Itoh et al. 2015]), along with simplification of the peptide mimic, generated NCDM-32B (Fig. 5), which restored specificity for KDM4 in vitro (Hamada et al. 2010), and suppressed growth of breast (Ye et al. 2015) and prostate cancer cells (Hamada et al. 2010) (the latter in combination with an LSD1 inhibitor). Yet another compound, methylstat (Fig. 5), featuring a similar hydroxamate group and a bulky substrate mimic, was specific for KDM4 and KDM6 demeth- ylases over PHF8 and FIH and inhibited KDM4C-mediated myogenesis in culture (Luo et al. 2011). These results reveal the power of inhibiting metal binding by chelation with hydroxamate, and more generally show that whereas peptide scaffolds can be exploited for specificity, the outcomes are difficult to predict a priori.

Although the bifunctional LSD1 and JmjC inhibitors share some similarities, it is noteworthy that the two classes have used conceptually different approaches. The JmjC inhibitors have aimed to displace both the substrate and the cofactor (either 2-OG and/or Fe(II)), whereas the LSD1 inhibitors have typically displaced only the substrate while irreversibly reacting 
Table 2. JmjC family inhibitors

\begin{tabular}{|c|c|c|c|c|c|}
\hline \multirow[b]{2}{*}{ Name } & \multicolumn{5}{|c|}{ In vitro } \\
\hline & $\begin{array}{l}\text { Where first } \\
\text { described }\end{array}$ & Inhibits & Does not inhibit & $\begin{array}{l}\text { Mouse tumor } \\
\text { studies }\end{array}$ & $\begin{array}{l}\text { Additional } \\
\text { references }\end{array}$ \\
\hline GSK-J4* & $\begin{array}{l}\text { Kruidenier } \\
\text { et al. } 2012\end{array}$ & $\begin{array}{l}\text { KDM5B, KDM5C, } \\
\text { KDM6A, } \\
\text { KDM6B }\end{array}$ & $\begin{array}{l}\text { KDM4A, KDM4C, } \\
\text { KDM4D, } \\
\text { KDM4E }\end{array}$ & $\begin{array}{l}\text { Ovarian cancer } \\
\text { xenograft }\end{array}$ & $\begin{array}{l}\text { Heinemann et al. } \\
\text { 2014; } \\
\text { Ntziachristos } \\
\text { et al. 2014; } \\
\text { Sakaki et al. } \\
\text { 2015; Horton } \\
\text { et al. } 2016\end{array}$ \\
\hline JIB-04* & $\begin{array}{l}\text { Wang et al. } \\
2013\end{array}$ & $\begin{array}{l}\text { KDM4A, KDM4B, } \\
\text { KDM4C, } \\
\text { KDM4E, } \\
\text { KDM6B }\end{array}$ & & $\begin{array}{l}\text { Non-small-cell } \\
\text { lung cancer } \\
\text { xenograft }\end{array}$ & Horton et al. 2016 \\
\hline SD70* & Jin et al. 2014 & KDM4C & & $\begin{array}{c}\text { Prostate cancer } \\
\text { xenograft }\end{array}$ & \\
\hline Compound 4 & $\begin{array}{c}\text { Chu et al. } \\
2014\end{array}$ & KDM4A, KDM4B & & & \\
\hline Compound 6p & $\begin{array}{l}\text { Feng et al. } \\
\quad 2015\end{array}$ & KDM4A & PHD2 & & \\
\hline Compound $6 \mathbf{j}$ & $\begin{array}{l}\text { Itoh et al. } \\
2015\end{array}$ & KDM5A & KDM4C, KDM3A & & \\
\hline Compound 13 & $\begin{array}{l}\text { Suzuki et al. } \\
2013\end{array}$ & $\begin{array}{l}\text { KDM2A, KDM7A, } \\
\text { KDM7B }\end{array}$ & $\begin{array}{l}\text { KDM4A, KDM4C, } \\
\text { KDM5A, } \\
\text { KDM6A }\end{array}$ & & \\
\hline $\begin{array}{l}\text { Compound } \\
3195\end{array}$ & $\begin{array}{l}\text { Mannironi } \\
\text { et al. } 2014\end{array}$ & KDM5A & & & \\
\hline Compound B3 & $\begin{array}{l}\text { Duan et al. } \\
2015\end{array}$ & KDM4B, KDM4D & KDM4A, KDM4C & & \\
\hline $\begin{array}{l}\text { Iridium }(\mathrm{III}) \\
\text { compound } 1\end{array}$ & Liu et al. 2015 & KDM4D & $\begin{array}{l}\text { KDM5A, KDM6B, } \\
\text { HDAC }\end{array}$ & & \\
\hline Methylstat & Luo et al. 2011 & $\begin{array}{r}\text { KDM4A, KDM4C, } \\
\text { KDM4E, KDM6 }\end{array}$ & $\begin{array}{l}\text { PHF8, FIH, LSD1, } \\
\text { HDAC }\end{array}$ & & \\
\hline NCDM-32B & $\begin{array}{l}\text { Hamada et al. } \\
2010\end{array}$ & KDM2A, KDM2C & PHD1, PHD2 & & \\
\hline PBIT & $\begin{array}{l}\text { Sayegh et al. } \\
2013\end{array}$ & $\begin{array}{l}\text { KDM5A, KDM5B, } \\
\text { KDM5C }\end{array}$ & KDM6A, KDM6B & & \\
\hline 2,4 PDCA & $\begin{array}{l}\text { Rose et al. } \\
\quad 2008\end{array}$ & $\begin{array}{l}\text { KDM2A, KDM3A, } \\
\text { KDM4A, } \\
\text { KDM4C, } \\
\text { KDM4D, } \\
\text { KDM4E, } \\
\text { PHD2, FIH }\end{array}$ & $\begin{array}{l}\text { KDM6A, KDM6B } \\
\quad \text { (weak } \\
\text { inhibition) }\end{array}$ & & $\begin{array}{l}\text { Hopkinson et al. } \\
2013\end{array}$ \\
\hline Compound 5 & $\begin{array}{l}\text { Schiller et al. } \\
2014\end{array}$ & KDM4C, KDM4E & $\begin{array}{l}\text { KDM2A, KDM3A, } \\
\text { KDM5C, } \\
\text { KDM6B, PHD2 }\end{array}$ & & \\
\hline Compound $7 f$ & $\begin{array}{l}\text { Rose et al. } \\
2010\end{array}$ & $\begin{array}{l}\text { KDM4A, KDM4E, } \\
\text { FIH }\end{array}$ & PHD2 & & \\
\hline Compound 9 & $\begin{array}{l}\text { Woon et al. } \\
2012\end{array}$ & KDM4A & $\begin{array}{l}\text { KDM2A, KDM4E, } \\
\text { PHF8 }\end{array}$ & & \\
\hline
\end{tabular}


A. Jambhekar et al.

Table 2. Continued

\begin{tabular}{|c|c|c|c|c|c|}
\hline \multirow[b]{2}{*}{ Name } & \multicolumn{5}{|c|}{ In vitro } \\
\hline & $\begin{array}{l}\text { Where first } \\
\text { described }\end{array}$ & Inhibits & Does not inhibit & $\begin{array}{l}\text { Mouse tumor } \\
\text { studies }\end{array}$ & $\begin{array}{l}\text { Additional } \\
\text { references }\end{array}$ \\
\hline Compound $15 c$ & $\begin{array}{l}\text { Chang et al. } \\
2011\end{array}$ & KDM4E & & & \\
\hline Compound 35 & $\begin{array}{l}\text { England et al. } \\
2014\end{array}$ & KDM2A & $\begin{array}{l}\text { KDM3A, KDM4A, } \\
\text { KDM4C, } \\
\text { KDM4E, } \\
\text { KDM5C, } \\
\text { KDM6B }\end{array}$ & & \\
\hline Compound 42 & $\begin{array}{l}\text { Korczynska } \\
\text { et al. } 2015\end{array}$ & $\begin{array}{l}\text { KDM3A, KDM4C, } \\
\text { KDM4D, } \\
\text { KDM5B }\end{array}$ & $\begin{array}{l}\text { KDM2A, KDM6B, } \\
\text { FIH }\end{array}$ & & \\
\hline Compound 47 & $\begin{array}{c}\text { Thalhammer } \\
\text { et al. } 2011\end{array}$ & KDM4E & PHD2 & & \\
\hline Daminozide & $\begin{array}{l}\text { Rose et al. } \\
\quad 2012\end{array}$ & $\begin{array}{l}\text { KDM2A, KDM7A, } \\
\text { PHF8 }\end{array}$ & $\begin{array}{l}\text { KDM3A, KDM4E, } \\
\text { KDM5C, } \\
\text { KDM6B, FIH, } \\
\text { PHD2, BBOX1 }\end{array}$ & & \\
\hline Disulfiram & $\begin{array}{l}\text { Sekirnik et al. } \\
2009\end{array}$ & $\begin{array}{l}\text { KDM4A, aldehyde } \\
\text { dehydrogenase, } \\
\text { HIV } \\
\text { nucleocapsid p7 }\end{array}$ & & & \\
\hline IOX1 & $\begin{array}{l}\text { King et al. } \\
2010\end{array}$ & $\begin{array}{l}\text { KDM3A, KDM4A, } \\
\text { KDM4C, } \\
\text { KDM4D, } \\
\text { KDM4E, } \\
\text { KDM6A, } \\
\text { KDM6B }\end{array}$ & $\begin{array}{l}\text { KDM2A, KDM5C, } \\
\text { PHF8, FIH, } \\
\text { PHD2 }\end{array}$ & & \\
\hline ML324 & Rai et al. 2010 & KDM4E & & & \\
\hline NOG & $\begin{array}{l}\text { Cloos et al. } \\
2006\end{array}$ & $\begin{array}{l}\text { KDM2A, KDM4A, } \\
\text { KDM4C, } \\
\text { KDM4D, } \\
\text { KDM5C, } \\
\text { KDM6A, } \\
\text { KDM6B, PHD2 }\end{array}$ & $\begin{array}{l}\text { KDM4E, PHF8, } \\
\text { FIH }\end{array}$ & & $\begin{array}{l}\text { Hopkinson et al. } \\
2013\end{array}$ \\
\hline
\end{tabular}

Inhibitors in bold have shown cytotoxic effects, and those marked with an asterisk have shown efficacy in animal models. In cases in which a single report described multiple, related compounds, only the most potent and/or selective one is listed. Specificity is reported based on the original authors' interpretation of their data; additional information can be found in the cited references.

with the cofactor. Second, with the exception of the compounds described by Rotili et al. (2014), none of the JmjC bifunctional inhibitors was designed to target two independent molecules simultaneously. Targeting other molecules in association with JmjC enzymes could be an effective approach to improving potency and specificity, and could open up novel strategies of inhibition, such as imposing steric constraints rather than simply inhibiting catalytic activity. The success of bifunctional inhibitors for both LSD1 and JmjC demethylases suggests that this strategy might be widely used to achieve specific inhibition, thus allowing use of compounds previously developed for targeting other enzymes. 


\section{OTHER JmjC INHIBITORS}

To identify novel scaffolds for JmjC demethylase inhibitors, several targeted and large-scale screens, including virtual screens, have been conducted, yielding molecules such as IOX1 (King et al. 2010) and compounds 35 (England et al. 2014) and 42 (Korczynska et al. 2015). In many screens, 8-hydroxyquinoline derivatives emerged as lead compounds. 5-carboxy-8-hydroxyquinoline (later named IOX1) (Fig. 4) was initially identified in a large screen as a potent and somewhat specific inhibitor of the KDM4 family (King et al. 2010; Hopkinson et al. 2013), and was later derivatized to improve cell permeability (compound 5 [Schiller et al. 2014]) (Fig. 4) and specificity (Feng et al. 2015), with a 2$1 \mathrm{H}$-benzo $[d]$ imidazole substituted compound (6p) (Fig. 5) inhibiting the proliferation of multiple types of cancer cells in culture (Feng et al. 2015). Other modifications of the parent $8 \mathrm{HQ}$ have improved both its potency in vivo and selectivity (e.g., ML324 [Rai et al. 2010; Liang et al. 2013b] and compound B3 [Duan et al. 2015]). Additional compounds identified by screening that inhibited JmjC enzymes in vitro and/or cancer cell growth in culture included a novel heterocycle, PBIT (Fig. 5) (Sayegh et al. 2013); catechols (Sakurai et al. 2010; Nielsen et al. 2012); bipyridyl compounds with carboxylates such as 2,4-PDCA (Rose et al. 2008) and compound 15c (Fig. 4) (Chang et al. 2011); the plant growth retardant daminozide, which chelates metal cofactors (Fig. 4) (Rose et al. 2012); and a dinitrobenzene derivative, compound 4 (Fig. 5) (Chu et al. 2014). Because daminozide was known to be toxic (Fan and Jackson 1989), a derivative (compound 13) containing a hydroxamate but lacking the potentially toxic 1,1-dimethylhydrazine structure was developed and shown to retain daminozide's preference for KDM2 and KDM7, and was effective in culture (Fig. 5) (Suzuki et al. 2013). Although the vast majority of inhibitors reported to date have been organic molecules, recently an iridiu$\mathrm{m}$ (III)-bipyridine complex (Fig. 5) was shown to inhibit KDM4 enzymes preferentially over KDM5A, KDM6A, or HDACs, and to inhibit lung cancer cell proliferation in culture (Liu et al. 2015). Together, these studies highlight the diversity of compounds capable of inhibiting JmjC family demethylases, and suggest that further screening may yield additional inhibitors. As is the case for the novel LSD1 inhibitors, many questions remain regarding the mechanisms of action of the JmjC inhibitors. For many inhibitors, their in vivo specificities, genome-wide effects on the distribution of methylated histones, and the expression and localizations of target and nontarget JmjC enzymes remain poorly defined. Furthermore, the efficacies of these inhibitors in animal models of cancer have not yet been reported; this information will be crucial for the development of JmjC inhibitors as therapeutics.

Three molecules identified by screening approaches have shown in vivo efficacy in mouse tumor models. The first, GSK-J4 (Fig. 5), was derived from a weak hit generated by screening the GlaxoSmithKline collection of two million compounds (Kruidenier et al. 2012). Guided by the crystal structure of KDM6A (JMJD3), Kruidenier et al. (2012) optimized interactions of the lead compound with the KDM6A active site to generate GSK-J1, which was reported to be specific for the KDM6 family of demethylases (Kruidenier et al. 2012). The cell-permeable analog, GSK-J4, suppressed KDM6A-mediated proinflammatory responses in macrophages, inhibited growth of breast cancer cells (Horton et al. 2016) in culture, and reduced tumor volume of ovarian cancer cells in mouse xenografts (Sakaki et al. 2015). GSK-J4 was also effective against T-cell acute lymphocytic leukemia (TALL) (Ntziachristos et al. 2014; Benyoucef et al. 2016). One study described an oncogenic role for KDM6B, and inhibition of leukemic cell growth was achieved in culture by treatment with GSK-J4 (Ntziachristos et al. 2014). Although this study also reported a tumor suppressive role for KDM6A (Ntziachristos et al. 2014), a subsequent study found that KDM6A functioned as an oncogene in T-ALLs driven by Tall (Benyoucef et al. 2016), a transcription factor commonly associated with this disease (Chen et al. 1990). Treatment of these cells with GSK-J4 inhibited proliferation and induced transcriptional programs similar to those 
A. Jambhekar et al.

observed on KDM6A knockdown, suggesting that KDM6A was the primary target of GSKJ4, and also inhibited T-ALL xenograft growth in a mouse model (Benyoucef et al. 2016). GSKJ1/4s reported specificity for the KDM6 family generated enthusiasm (Harrison 2012), but soon Heinemann et al. (2014) showed that the molecules inhibited other JmjC family demethylases not initially tested. These results reveal the importance of testing potential specific inhibitors against a broad panel of 2-OG-dependent enzymes, as some inhibitors may react with a more distantly related family member rather than a close one. Given that KDM6A cooperates with other histone methylation regulators such as LSD1 (in the case of Tall-driven transcription [Hu et al. 2009]) and the H3K4 methyltransferse MLL2 (Cho et al. 2007; Issaeva et al. 2007), it is possible that some of the effects of GSK-J1/4 on T-ALL could arise from inhibition of other demethylases operating in the same pathways. Nevertheless, the effectiveness of GSKJ1/4 in animal tumor models suggests potential therapeutic uses.

Two other screening approaches have yielded additional inhibitors of JmjC-family enzymes that are active. One screening approach, based on the expression of a GFP reporter, yielded JIB-04 (Fig. 5), which was identified as a demethylase inhibitor based on the similarity of the expression profiles of JIB-04-treated cells with those of cells treated with inhibitors of 2OG-dependent enzymes (Wang et al. 2013). JIB-04 prolonged the survival of mice bearing orthotopic mammary tumors (Horton et al. 2016). A more targeted screen of molecules regulating epigenetic or nuclear factors yielded SD70 (Fig. 5), an 8-HQ derivative that localized to enhancers and inhibited KDM4C in vitro, and decreased the tumor volume of prostate cancer xenografts in mice (Jin et al. 2014). Importantly, "Chem-Seq" pull-down experiments (Anders et al. 2014)—which used a biotin tag on SD70 to isolate the molecule from cells, followed by high-throughput sequencing to identify the genomic regions to which it localized (via binding to its target proteins or DNA) revealed that the genomic localization sites of SD70 overlapped with androgen receptor (AR) enhancer sites, and that SD70 inhibited expression of the AR target genes. These results provide valuable information on the molecular effects of the inhibitor, suggesting that the drug might interfere with the catalytic activity of KDM4C, but have minimal effects on its targeting to enhancers. Chem-Seq could be a powerful approach for investigating the molecular mechanisms of other inhibitors, provided that the linker and biotin tag are tolerated by the target enzymes.

\section{CONCLUDING REMARKS}

The success of histone demethylase inhibitors in decreasing the growth of many types of cancer cells in culture points to the potential for further developing these molecules for clinical use. A major obstacle toward this goal is achieving specific inhibition of key demethylases, as most inhibitors thus far act on related enzymes (other demethylases as well as enzymes using the same catalytic strategy). Although specific inhibitors are less likely to induce toxicity or side effects, pan- (or multi-) demethylase inhibitors could also be useful (as observed for HDAC inhibitors), as several demethylases show functional redundancies. A second challenge lies in predicting the transcriptional and cellular outcomes of demethylase inhibition. As discussed earlier, demethylase activity can affect transcriptional outputs in different ways, depending on cell type, and the key demethylase target genes that contribute to unrestrained cell proliferation vary between cancers. Therefore, predicting which demethylases to inhibit, and to what extent, may be challenging, as achieving a fine balance of histone modifications genomewide is critical for normal cell function. Furthermore, recent work has revealed nonhistone substrates for histone demethylases, including regulation of p53 (Huang et al. 2007a) and E2F1 (Kontaki and Talianidis 2010) by LSD1mediated demethylation, and a cytoplasmic role for KDM4A in promoting translation (Van Rechem et al. 2015). In accord with their homology with 2-OG oxygenases, some JmjC enzymes have also been reported to hydroxylate proteins, such as the splicing factor U2AF65 (Webby et al. 
Histone Lysine Demethylase Inhibitors

2009). Thus, it is possible that some of the cellular and in vivo effects of demethylase inhibitors arise from altered methylation of nonhistone substrates, instead of (or in addition to) effects on histone methylation. Given the pleiotropic roles of demethylases, it is remarkable that studies targeting overexpressed demethylases in cancer have met with success, and these studies hold promise for successful application of this strategy. Finally, demethylase inhibitors are not immune to the usual challenges of drug design such as achieving stability and cell permeability; in fact, some strong inhibitors such as NOG derivatives (Hamada et al. 2009) have already shown poor efficacy in vivo despite their inhibitory activity in vitro. Nevertheless, epigenetic modifiers represent unique drug targets, as their inhibition can be effective at blocking cell proliferation even if other mutations underlie the cancer phenotype. Therefore, further development of the demethylase inhibitors holds the promise of generating effective therapies for a wide range of cancers, either singly or in combination with other chromatin-targeting agents (e.g., Huang et al. 2009; Singh et al. 2011; Huang et al. 2012; Vasilatos et al. 2013; Fiskus et al. 2014), differentiation therapies (Schenk et al. 2012), or immunotherapeutics (Maio 2015).

\section{ACKNOWLEDGMENTS}

This work is supported by grants from the National Institutes of Health (CA118487 and MH096066) and an Ellison Foundation Senior Scholar Award to Y.S., and grants from the National Cancer Institute (5F32CA189741-02), Rally Foundation for Pediatric Cancer Research, and the Vs. Cancer Foundation to J.N.A. Y.S. is an American Cancer Society Research Professor. Y.S. is a cofounder of Constellation Pharmaceuticals and a member of its scientific advisory board and is a consultant for Active Motif.

\section{REFERENCES}

Abdulla A, Zhao X, Yang F. 2013. Natural polyphenols inhibit lysine-specific demethylase-1. J Biochem Pharmacol Res 1: 56-63.
Agger K, Cloos PA, Christensen J, Pasini D, Rose S, Rappsilber J, Issaeva I, Canaani E, Salcini AE, Helin K. 2007. UTX and JMJD3 are histone H3K27 demethylases involved in HOX gene regulation and development. Nature 449: 731-734.

Agin HV. 1960. Tranylcypromine in depression: A clinical report. Am J Psychiatry 117: 150-151.

Anders L, Guenther MG, Qi J, Fan ZP, Marineau JJ, Rahl PB, Loven J, Sigova AA, Smith WB, Lee TI, et al. 2014. Genome-wide localization of small molecules. Nat Biotechnol 32: 92-96.

Baader E, Tschank G, Baringhaus KH, Burghard H, Gunzler V. 1994. Inhibition of prolyl 4-hydroxylase by oxalyl amino acid derivatives in vitro, in isolated microsomes and in embryonic chicken tissues. Biochem J 300: 525-530.

Bannister AJ, Schneider R, Kouzarides T. 2002. Histone methylation: Dynamic or static? Cell 109: 801-806.

Baron R, Binda C, Tortorici M, McCammon JA, Mattevi A. 2011. Molecular mimicry and ligand recognition in binding and catalysis by the histone demethylase LSD1-CoREST complex. Structure 19: 212-220.

Barski A, Cuddapah S, Cui K, Roh TY, Schones DE, Wang Z, Wei G, Chepelev I, Zhao K. 2007. High-resolution profiling of histone methylations in the human genome. Cell 129: $823-837$.

Benelkebir H, Hodgkinson C, Duriez PJ, Hayden AL, Bulleid RA, Crabb SJ, Packham G, Ganesan A. 2011. Enantioselective synthesis of tranylcypromine analogues as lysine demethylase (LSD1) inhibitors. Bioorg Med Chem 19: 3709-3716.

Benyoucef A, Palii CG, Wang C, Porter CJ, Chu A, Dai F, Tremblay V, Rakopoulos P, Singh K, Huang S, et al. 2016 UTX inhibition as selective epigenetic therapy against TAL1-driven T-cell acute lymphoblastic leukemia. Genes Dev 30: 508-521.

Berry WL, Shin S, Lightfoot SA, Janknecht R. 2012. Oncogenic features of the JMJD2A histone demethylase in breast cancer. Int J Oncol 41: 1701-1706.

Bianchi M, Polticelli F, Ascenzi P, Botta M, Federico R, Mariottini P, Cona A. 2006. Inhibition of polyamine and spermine oxidases by polyamine analogues. FEBS J 273: 1115-1123.

Binda C, Valente S, Romanenghi M, Pilotto S, Cirilli R, Karytinos A, Ciossani G, Botrugno OA, Forneris F, Tardugno M, et al. 2010. Biochemical, structural, and biological evaluation of tranylcypromine derivatives as inhibitors of histone demethylases LSD1 and LSD2. J Am Chem Soc 132: 6827-6833.

Chang KH, King ON, Tumber A, Woon EC, Heightman TD, McDonough MA, Schofield CJ, Rose NR. 2011. Inhibition of histone demethylases by 4-carboxy-2,2'-bipyridyl compounds. ChemMedChem 6: 759-764.

Chen Q, Cheng JT, Tasi LH, Schneider N, Buchanan G, Carroll A, Crist W, Ozanne B, Siciliano MJ, Baer R. 1990. The tal gene undergoes chromosome translocation in T cell leukemia and potentially encodes a helix-loophelix protein. EMBO J 9: 415-424.

Chen Y, Yang Y, Wang F, Wan K, Yamane K, Zhang Y, Lei M. 2006. Crystal structure of human histone lysine-specific demethylase 1 (LSD1). Proc Natl Acad Sci 103: 1395613961. 
A. Jambhekar et al.

Chen Z, Zang J, Kappler J, Hong X, Crawford F, Wang Q, Lan F, Jiang C, Whetstine J, Dai S, et al. 2007. Structural basis of the recognition of a methylated histone tail by JMJD2A. Proc Natl Acad Sci 104: 10818-10823.

Chen QW, Zhu XY, Li YY, Meng ZQ. 2014. Epigenetic regulation and cancer (review). Oncol Rep 31: 523-532.

Cho YW, Hong T, Hong S, Guo H, Yu H, Kim D, Guszczynski T, Dressler GR, Copeland TD, Kalkum M, et al. 2007. PTIP associates with MLL3- and MLL4-containing histone $\mathrm{H} 3$ lysine 4 methyltransferase complex. J Biol Chem 282: 20395-20406.

Chu CH, Wang LY, Hsu KC, Chen CC, Cheng HH, Wang SM, Wu CM, Chen TJ, Li LT, Liu R, et al. 2014. KDM4B as a target for prostate cancer: Structural analysis and selective inhibition by a novel inhibitor. J Med Chem 57: 5975-5985.

Cloos PA, Christensen J, Agger K, Maiolica A, Rappsilber J, Antal T, Hansen KH, Helin K. 2006. The putative oncogene GASC1 demethylates tri- and dimethylated lysine 9 on histone H3. Nature 442: 307-311.

Cortez V, Mann M, Tekmal S, Suzuki T, Miyata N, Rodriguez-Aguayo C, Lopez-Berestein G, Sood AK, Vadlamudi RK. 2012. Targeting the PELP1-KDM1 axis as a potential therapeutic strategy for breast cancer. Breast Cancer Res 14: R108.

Couture JF, Collazo E, Ortiz-Tello PA, Brunzelle JS, Trievel RC. 2007. Specificity and mechanism of JMJD2A, a trimethyllysine-specific histone demethylase. Nat Struct Mol Biol 14: 689-695.

Culhane JC, Szewczuk LM, Liu X, Da G, Marmorstein R, Cole PA. 2006. A mechanism-based inactivator for histone demethylase LSD1. J Am Chem Soc 128: 4536-4537.

Culhane JC, Wang D, Yen PM, Cole PA. 2010. Comparative analysis of small molecules and histone substrate analogues as LSD1 lysine demethylase inhibitors. J Am Chem Soc 132: 3164-3176.

Dalgliesh GL, Furge K, Greenman C, Chen L, Bignell G, Butler A, Davies H, Edkins S, Hardy C, Latimer C, et al. 2010. Systematic sequencing of renal carcinoma reveals inactivation of histone modifying genes. Nature 463: 360-363.

Ding J, Zhang ZM, Xia Y, Liao GQ, Pan Y, Liu S, Zhang Y, Yan ZS. 2013. LSD1-mediated epigenetic modification contributes to proliferation and metastasis of colon cancer. Br J Cancer 109: 994-1003.

Duan L, Rai G, Roggero C, Zhang QJ, Wei Q, Ma SH, Zhou Y, Santoyo J, Martinez ED, Xiao G, et al. 2015. KDM4/ JMJD2 histone demethylase inhibitors block prostate tumor growth by suppressing the expression of AR and BMYB-regulated genes. Chem Biol 22: 1185-1196.

Dulla B, Kirla KT, Rathore V, Deora GS, Kavela S, Maddika S, Chatti K, Reiser O, Iqbal J, Pal M. 2013. Synthesis and evaluation of 3-amino/guanidine substituted phenyl oxazoles as a novel class of LSD1 inhibitors with anti-proliferative properties. Org Biomol Chem 11: 3103-3107.

Ehrbrecht A, Muller U, Wolter M, Hoischen A, Koch A, Radlwimmer B, Actor B, Mincheva A, Pietsch T, Lichter P, et al. 2006. Comprehensive genomic analysis of desmoplastic medulloblastomas: Identification of novel amplified genes and separate evaluation of the different histological components. J Pathol 208: 554-563.
Elkins JM, Hewitson KS, McNeill LA, Seibel JF, Schlemminger I, Pugh CW, Ratcliffe PJ, Schofield CJ. 2003. Structure of factor-inhibiting hypoxia-inducible factor (HIF) reveals mechanism of oxidative modification of HIF-1 $\alpha$. J Biol Chem 278: 1802-1806.

Ellis PM, Dronsfield AT. 2013. Antabuse's diamond anniversary: Still sparkling on? Drug Alcohol Rev 32: 342-344.

England KS, Tumber A, Krojer T, Scozzafava G, Ng SS, Daniel M, Szykowska A, Che K, von Delft F, Burgess-Brown NA, et al. 2014. Optimisation of a triazolopyridine based histone demethylase inhibitor yields a potent and selective KDM2A (FBXL11) inhibitor. MedChemComm 5: 1879-1886.

Etani T, Suzuki T, Naiki T, Naiki-Ito A, Ando R, Iida K, Kawai N, Tozawa K, Miyata N, Kohri K, et al. 2015. NCL1, a highly selective lysine-specific demethylase 1 inhibitor, suppresses prostate cancer without adverse effect. Oncotarget 6: 2865-2878.

Fan AM, Jackson RJ. 1989. Pesticides and food safety. Regul Toxicol Pharmacol 9: 158-174.

Fang R, Barbera AJ, Xu Y, Rutenberg M, Leonor T, Bi Q, Lan F, Mei P, Yuan GC, Lian C, et al. 2010. Human LSD2/ $\mathrm{KDM} 1 \mathrm{~b} / \mathrm{AOF} 1$ regulates gene transcription by modulating intragenic H3K4me2 methylation. Mol Cell 39: 222 233.

Feldman JM, Chapman B. 1975. Monoamine oxidase inhibitors: Nature of their interaction with rabbit pancreatic islets to alter insulin secretion. Diabetologia 11: 487-494.

Feng T, Li D, Wang H, Zhuang J, Liu F, Bao Q, Lei Y, Chen W, Zhang X, Xu X, et al. 2015. Novel 5-carboxy-8-HQ based histone demethylase JMJD2A inhibitors: Introduction of an additional carboxyl group at the $\mathrm{C}-2$ position of quinoline. Eur J Med Chem 105: 145-155.

Ferrari-Amorotti G, Fragliasso V, Esteki R, Prudente Z, Soliera AR, Cattelani S, Manzotti G, Grisendi G, Dominici M, Pieraccioli M, et al. 2013. Inhibiting interactions of lysine demethylase LSD1 with snail/slug blocks cancer cell invasion. Cancer Res 73: 235-245.

Ferrari-Amorotti G, Chiodoni C, Shen F, Cattelani S, Soliera AR, Manzotti G, Grisendi G, Dominici M, Rivasi F, Colombo MP, et al. 2014. Suppression of invasion and metastasis of triple-negative breast cancer lines by pharmacological or genetic inhibition of slug activity. Neoplasia 16: $1047-1058$.

Fiskus W, Sharma S, Shah B, Portier BP, Devaraj SG, Liu K, Iyer SP, Bearss D, Bhalla KN. 2014. Highly effective combination of LSD1 (KDM1A) antagonist and pan-histone deacetylase inhibitor against human AML cells. Leukemia 28: $2155-2164$.

Garcia-Bassets I, Kwon YS, Telese F, Prefontaine GG, Hutt KR, Cheng CS, Ju BG, Ohgi KA, Wang J, Escoubet-Lozach L, et al. 2007. Histone methylation-dependent mechanisms impose ligand dependency for gene activation by nuclear receptors. Cell 128: 505-518.

George T, Kaul CL, Grewal RS, Tahilramani R. 1971. Antihypertensive and monoamine oxidase inhibitory activity of some derivatives of 3-formyl-4-oxo-4H-pyrido (1,2-a) pyrimidine. J Med Chem 14: 913-915.

Gough SM, Lee F, Yang F, Walker RL, Zhu YJ, Pineda M, Onozawa M, Chung YJ, Bilke S, Wagner EK, et al. 2014. NUP98-PHF23 is a chromatin-modifying oncoprotein that causes a wide array of leukemias sensitive to inhibi- 
tion of PHD histone reader function. Cancer Discov 4: $564-577$.

Gui Y, Guo G, Huang Y, Hu X, Tang A, Gao S, Wu R, Chen C, Li X, Zhou L, et al. 2011. Frequent mutations of chromatin remodeling genes in transitional cell carcinoma of the bladder. Nat Genet 43: 875-878.

Hamada S, Kim TD, Suzuki T, Itoh Y, Tsumoto H, Nakagawa H, Janknecht R, Miyata N. 2009. Synthesis and activity of $\mathrm{N}$-oxalylglycine and its derivatives as Jumonji C-domain-containing histone lysine demethylase inhibitors. Bioorg Med Chem Lett 19: 2852-2855.

Hamada S, Suzuki T, Mino K, Koseki K, Oehme F, Flamme I, Ozasa H, Itoh Y, Ogasawara D, Komaarashi H, et al. 2010. Design, synthesis, enzyme-inhibitory activity, and effect on human cancer cells of a novel series of Jumonji domain-containing protein 2 histone demethylase inhibitors. J Med Chem 53: 5629-5638.

Han Y, Wu C, Lv H, Liu N, Deng H. 2015. Novel tranylcypromine/hydroxylcinnamic acid hybrids as lysine-specific demethylase 1 inhibitors with potent antitumor activity. Chem Pharm Bull (Tokyo) 63: 882-889.

Harris WJ, Huang X, Lynch JT, Spencer GJ, Hitchin JR, Li Y, Ciceri F, Blaser JG, Greystoke BF, Jordan AM, et al. 2012. The histone demethylase KDM1A sustains the oncogenic potential of MLL-AF9 leukemia stem cells. Cancer Cell 21: $473-487$.

Harrison C. 2012. Structure-based drug design: Opening the door to an epigenetic target. Nat Rev Drug Discov 11: 672 .

Hayami S, Kelly JD, Cho HS, Yoshimatsu M, Unoki M, Tsunoda T, Field HI, Neal DE, Yamaue H, Ponder BA, et al. 2011. Overexpression of LSD1 contributes to human carcinogenesis through chromatin regulation in various cancers. Int J Cancer 128: 574-586.

Heinemann B, Nielsen JM, Hudlebusch HR, Lees MJ, Larsen DV, Boesen T, Labelle M, Gerlach LO, Birk P, Helin K. 2014. Inhibition of demethylases by GSK-J1/J4. Nature 514: E1-E2.

Heydendael W, Jacobson L. 2009. Glucocorticoid status affects antidepressant regulation of locus coeruleus tyrosine hydroxylase and dorsal raphe tryptophan hydroxylase gene expression. Brain Res 1288: 69-78.

Hitchin JR, Blagg J, Burke R, Burns S, Cockerill MJ, Fairweather EE, Hutton C, Jordan AM, McAndrew C, Mirza A, et al. 2013. Development and evaluation of selective, reversible LSD1 inhibitors derived from fragments. Medchemcomm 4: 1513-1522.

Hojfeldt JW, Agger K, Helin K. 2013. Histone lysine demethylases as targets for anticancer therapy. Nat Rev Drug Discov 12: 917-930.

Hopkinson RJ, Tumber A, Yapp C, Chowdhury R, Aik W, Che KH, Li XS, Kristensen JB, King ON, Chan MC, et al. 2013. 5-Carboxy-8-hydroxyquinoline is a broad spectrum 2-oxoglutarate oxygenase inhibitor which causes iron translocation. Chem Sci 4: 3110-3117.

Horton JR, Engstrom A, Zoeller EL, Liu X, Shanks JR, Zhang X, Johns MA, Vertino PM, Fu H, Cheng X. 2016. Characterization of a linked Jumonji domain of the KDM5/ JARID1 family of histone $\mathrm{H} 3$ lysine 4 demethylases. J Biol Chem 291: 2631-2646.

Hoshino I, Akutsu Y, Murakami K, Akanuma N, Isozaki Y, Maruyama T, Toyozumi T, Matsumoto Y, Suito H, Taka- hashi M, et al. 2016. Histone demethylase LSD1 inhibitors prevent cell growth by regulating gene expression in esophageal squamous cell carcinoma cells. Ann Surg Oncol 23: $312-320$

Hu X, Li X, Valverde K, Fu X, Noguchi C, Qiu Y, Huang S. 2009. LSD1-mediated epigenetic modification is required for TAL1 function and hematopoiesis. Proc Natl Acad Sci 106: 10141-10146.

Huang J, Sengupta R, Espejo AB, Lee MG, Dorsey JA, Richter M, Opravil S, Shiekhattar R, Bedford MT, Jenuwein T, et al. 2007a. p53 is regulated by the lysine demethylase LSD1. Nature 449: 105-108.

Huang Y, Greene E, Murray Stewart T, Goodwin AC, Baylin SB, Woster PM, Casero RA Jr. 2007b. Inhibition of lysinespecific demethylase 1 by polyamine analogues results in reexpression of aberrantly silenced genes. Proc Natl Acad Sci 104: 8023-8028.

Huang Y, Stewart TM, Wu Y, Baylin SB, Marton LJ, Perkins B, Jones RJ, Woster PM, Casero RA Jr. 2009. Novel oligoamine analogues inhibit lysine-specific demethylase 1 and induce reexpression of epigenetically silenced genes. Clin Cancer Res 15: 7217-7228.

Huang Y, Vasilatos SN, Boric L, Shaw PG, Davidson NE. 2012. Inhibitors of histone demethylation and histone deacetylation cooperate in regulating gene expression and inhibiting growth in human breast cancer cells. Breast Cancer Res Treat 131: 777-789.

Issaeva I, Zonis Y, Rozovskaia T, Orlovsky K, Croce CM, Nakamura T, Mazo A, Eisenbach L, Canaani E. 2007. Knockdown of ALR (MLL2) reveals ALR target genes and leads to alterations in cell adhesion and growth. Mol Cell Biol 27: 1889-1903.

Itoh Y, Sawada H, Suzuki M, Tojo T, Sasaki R, Hasegawa M, Mizukami T, Suzuki T. 2015. Identification of Jumonji AT-rich interactive domain $1 \mathrm{~A}$ inhibitors and their effect on cancer cells. ACS Med Chem Lett 6: 665-670.

Jenuwein T, Allis CD. 2001. Translating the histone code. Science 293: 1074-1080.

Jin C, Yang L, Xie M, Lin C, Merkurjev D, Yang JC, Tanasa B, Oh S, Zhang J, Ohgi KA, et al. 2014. Chem-seq permits identification of genomic targets of drugs against androgen receptor regulation selected by functional phenotypic screens. Proc Natl Acad Sci 111: 9235-9240.

Kakizawa T, Ota Y, Itoh Y, Tsumoto H, Suzuki T. 2015. Histone $\mathrm{H} 3$ peptide based LSD1-selective inhibitors. Bioorg Med Chem Lett 25: 1925-1928.

Karytinos A, Forneris F, Profumo A, Ciossani G, Battaglioli E, Binda C, Mattevi A. 2009. A novel mammalian flavindependent histone demethylase. J Biol Chem 284: 1777517782.

Kauffman EC, Robinson BD, Downes MJ, Powell LG, Lee MM, Scherr DS, Gudas LJ, Mongan NP. 2011. Role of androgen receptor and associated lysine-demethylase coregulators, LSD1 and JMJD2A, in localized and advanced human bladder cancer. Mol Carcinog 50: 931944.

Khan MNA, Tsumoto H, Itoh Y, Ota Y, Suzuki M, Ogasawara D, Nakagawa H, Mizukami T, Miyata N, Suzuki T. 2015. Design, synthesis, and biological activity of $N$-alkylated analogue of NCL1, a selective inhibitor of lysine-specific demethylase 1. Med Chem Commun 6: 407-412. 
A. Jambhekar et al.

Kim TD, Fuchs JR, Schwartz E, Abdelhamid D, Etter J, Berry WL, Li C, Ihnat MA, Li PK, Janknecht R. 2014. Progrowth role of the JMJD2C histone demethylase in HCT-116 colon cancer cells and identification of curcuminoids as JMJD2 inhibitors. Am J Transl Res 6: 236247.

King ON, Li XS, Sakurai M, Kawamura A, Rose NR, Ng SS, Quinn AM, Rai G, Mott BT, Beswick P, et al. 2010. Quantitative high-throughput screening identifies 8-hydroxyquinolines as cell-active histone demethylase inhibitors. PLOS ONE 5: e15535.

Klose RJ, Yamane K, Bae Y, Zhang D, Erdjument-Bromage $\mathrm{H}$, Tempst P, Wong J, Zhang Y. 2006. The transcriptional repressor JHDM3A demethylates trimethyl histone $\mathrm{H} 3$ lysine 9 and lysine 36. Nature 442: 312-316.

Konovalov S, Garcia-Bassets I. 2013. Analysis of the levels of lysine-specific demethylase 1 (LSD1) mRNA in human ovarian tumors and the effects of chemical LSD1 inhibitors in ovarian cancer cell lines. J Ovarian Res 6: 75.

Kontaki H, Talianidis I. 2010. Lysine methylation regulates E2F1-induced cell death. Mol Cell 39: 152-160.

Korczynska M, Le DD, Younger N, Gregori-Puigjane E, Tumber A, Krojer T, Velupillai S, Gileadi C, Nowak RP, Iwasa E, et al. 2015. Docking and linking of fragments to discover Jumonji histone demethylase inhibitors. J Med Chem 59: 1580-1598.

Kouzarides T. 2007. Chromatin modifications and their function. Cell 128: 693-705.

Kristensen LH, Nielsen AL, Helgstrand C, Lees M, Cloos P, Kastrup JS, Helin K, Olsen L, Gajhede M. 2012. Studies of H3K4me3 demethylation by KDM5B/Jarid1B/PLU1 reveals strong substrate recognition in vitro and identifies 2,4-pyridine-dicarboxylic acid as an in vitro and in cell inhibitor. FEBS J 279: 1905-1914.

Kruidenier L, Chung CW, Cheng Z, Liddle J, Che K, Joberty G, Bantscheff M, Bountra C, Bridges A, Diallo H, et al. 2012. A selective Jumonji H3K27 demethylase inhibitor modulates the proinflammatory macrophage response. Nature 488: 404-408.

Labbe RM, Holowatyj A, Yang ZQ. 2013. Histone lysine demethylase (KDM) subfamily 4: Structures, functions and therapeutic potential. Am J Transl Res 6: 1-15.

Lan F, Bayliss PE, Rinn JL, Whetstine JR, Wang JK, Chen S, Iwase S, Alpatov R, Issaeva I, Canaani E, et al. 2007. A histone $\mathrm{H} 3$ lysine 27 demethylase regulates animal posterior development. Nature 449: 689-694.

Laurent B, Ruitu L, Murn J, Hempel K, Ferrao R, Xiang Y, Liu S, Garcia BA, Wu H, Wu F, et al. 2015. A specific LSD1/KDM1A isoform regulates neuronal differentiation through H3K9 demethylation. Mol Cell 57: 957970.

Lee MG, Wynder C, Cooch N, Shiekhattar R. 2005. An essential role for CoREST in nucleosomal histone 3 lysine 4 demethylation. Nature 437: 432-435.

Lee MG, Wynder C, Schmidt DM, McCafferty DG, Shiekhattar R. 2006. Histone H3 lysine 4 demethylation is a target of nonselective antidepressive medications. Chem Biol 13: 563-567.

Liang Y, Quenelle D, Vogel JL, Mascaro C, Ortega A, Kristie TM. 2013a. A novel selective LSD1/KDM1A inhibitor epigenetically blocks herpes simplex virus lytic replica- tion and reactivation from latency. MBio 4: e00558e00512.

Liang Y, Vogel JL, Arbuckle JH, Rai G, Jadhav A, Simeonov A, Maloney DJ, Kristie TM. 2013b. Targeting the JMJD2 histone demethylases to epigenetically control herpesvirus infection and reactivation from latency. Sci Transl Med 5: 167ra165.

Lienhart WD, Gudipati V, Macheroux P. 2013. The human flavoproteome. Arch Biochem Biophys 535: 150-162.

Ling Y, Wang Z, Wang X, Zhao Y, Zhang W, Wang X, Chen L, Huang Z, Zhang Y. 2014. Synthesis and biological evaluation of hybrids from farnesylthiosalicylic acid and hydroxylcinnamic acid with dual inhibitory activities of Ras-related signaling and phosphorylated NF-кB. Org Biomol Chem 12: 4517-4530.

Liu G, Bollig-Fischer A, Kreike B, van de Vijver MJ, Abrams J, Ethier SP, Yang ZQ. 2009. Genomic amplification and oncogenic properties of the GASC1 histone demethylase gene in breast cancer. Oncogene 28: 4491-4500.

Liu LJ, Lu L, Zhong HJ, He B, Kwong DW, Ma DL, Leung CH. 2015. An iridium(III) complex inhibits JMJD2 activities and acts as a potential epigenetic modulator. $J$ Med Chem 58: 6697-6703.

Luger K, Mader AW, Richmond RK, Sargent DF, Richmond TJ. 1997. Crystal structure of the nucleosome core particle at 2.8 A resolution. Nature 389: 251-260.

Luo X, Liu Y, Kubicek S, Myllyharju J, Tumber A, Ng S, Che KH, Podoll J, Heightman TD, Oppermann U, et al. 2011. A selective inhibitor and probe of the cellular functions of Jumonji C domain-containing histone demethylases. $J$ Am Chem Soc 133: 9451-9456.

Lv T, Yuan D, Miao X, Lv Y, Zhan P, Shen X, Song Y. 2012. Over-expression of LSD1 promotes proliferation, migration and invasion in non-small cell lung cancer. PLoS ONE 7: e35065.

Ma LY, Zheng YC, Wang SQ, Wang B, Wang ZR, Pang LP, Zhang M, Wang JW, Ding L, Li J, et al. 2015. Design, synthesis, and structure-activity relationship of novel LSD1 inhibitors based on pyrimidine-thiourea hybrids as potent, orally active antitumor agents. J Med Chem $\mathbf{5 8 :}$ 1705-1716.

Mackeen MM, Kramer HB, Chang KH, Coleman ML, Hopkinson RJ, Schofield CJ, Kessler BM. 2010. Small-molecule-based inhibition of histone demethylation in cells assessed by quantitative mass spectrometry. J Proteome Res 9: 4082-4092.

Maes T, Carceller E, Salas J, Ortega A, Buesa C. 2015. Advances in the development of histone lysine demethylase inhibitors. Curr Opin Pharmacol 23: 52-60.

Mai A, Cheng D, Bedford MT, Valente S, Nebbioso A, Perrone A, Brosch G, Sbardella G, De Bellis F, Miceli M, et al. 2008. Epigenetic multiple ligands: Mixed histone/protein methyltransferase, acetyltransferase, and class III deacetylase (sirtuin) inhibitors. J Med Chem 51: 22792290.

Maio M, Covre A, Fratta E, Di Giacomo AM, Taverna P, Natali PG, Coral S, Sigalotti L. 2015. Molecular pathways: At the crossroads of cancer epigenetics and immunotherapy. Clin Cancer Res 21: 4040-4047.

Mannironi C, Proietto M, Bufalieri F, Cundari E, Alagia A, Danovska S, Rinaldi T, Famiglini V, Coluccia A, La Regina G, et al. 2014. An high-throughput in vivo screening 
system to select H3K4-specific histone demethylase inhibitors. PLOS ONE 9: e86002.

Martin C, Zhang Y. 2005. The diverse functions of histone lysine methylation. Nat Rev Mol Cell Biol 6: 838-849.

Metzger E, Wissmann M, Yin N, Muller JM, Schneider R, Peters AH, Gunther T, Buettner R, Schule R. 2005. LSD1 demethylates repressive histone marks to promote androgen-receptor-dependent transcription. Nature 437: 436439.

Mimasu S, Umezawa N, Sato S, Higuchi T, Umehara T, Yokoyama S. 2010. Structurally designed trans-2-phenylcyclopropylamine derivatives potently inhibit histone demethylase LSD1/KDM1. Biochemistry 49: 6494-6503.

Murray-Stewart T, Woster PM, Casero RA Jr. 2014. The reexpression of the epigenetically silenced e-cadherin gene by a polyamine analogue lysine-specific demethylase- 1 (LSD1) inhibitor in human acute myeloid leukemia cell lines. Amino Acids 46: 585-594.

Nakamura S, Tan L, Nagata Y, Takemura T, Asahina A, Yokota D, Yagyu T, Shibata K, Fujisawa S, Ohnishi K. 2013. JmjC-domain containing histone demethylase 1B-mediated $\mathrm{p} 15$ (Ink $4 \mathrm{~b}$ ) suppression promotes the proliferation of leukemic progenitor cells through modulation of cell cycle progression in acute myeloid leukemia. Mol Carcinog 52: 57-69.

Neelamegam R, Ricq EL, Malvaez M, Patnaik D, Norton S, Carlin SM, Hill IT, Wood MA, Haggarty SJ, Hooker JM. 2012. Brain-penetrant LSD1 inhibitors can block memory consolidation. ACS Chem Neurosci 3: 120-128.

Nielsen AL, Kristensen LH, Stephansen KB, Kristensen JB, Helgstrand C, Lees M, Cloos P, Helin K, Gajhede M, Olsen L. 2012. Identification of catechols as histone-lysine demethylase inhibitors. FEBS Lett 586: 1190-1194.

Nowotarski SL, Pachaiyappan B, Holshouser SL, Kutz CJ, Li Y, Huang Y, Sharma SK, Casero RA Jr, Woster PM. 2015. Structure-activity study for (bis)ureidopropyl- and (bis)thioureidopropyldiamine LSD1 inhibitors with 3 5-3 and 3-6-3 carbon backbone architectures. Bioorg Med Chem 23: 1601-1612.

Ntziachristos P, Tsirigos A, Welstead GG, Trimarchi T, Bakogianni S, Xu L, Loizou E, Holmfeldt L, Strikoudis A, King B, et al. 2014. Contrasting roles of histone 3 lysine 27 demethylases in acute lymphoblastic leukaemia. Nature 514: 513-517.

Ogasawara D, Suzuki T, Mino K, Ueda R, Khan MN, Matsubara T, Koseki K, Hasegawa M, Sasaki R, Nakagawa H, et al. 2011. Synthesis and biological activity of optically active NCL-1, a lysine-specific demethylase 1 selective inhibitor. Bioorg Med Chem 19: 3702-3708.

Oreland L, Kinemuchi H, Yoo BY. 1973. The mechanism of action of the monoamine oxidase inhibitor pargyline. Life Sci 13: 1533-1541.

Paik WK, Kim S. 1973. Enzymatic demethylation of calf thymus histones. Biochem Biophys Res Commun 51: 781-788.

Perillo B, Ombra MN, Bertoni A, Cuozzo C, Sacchetti S, Sasso A, Chiariotti L, Malorni A, Abbondanza C, Avvedimento EV. 2008. DNA oxidation as triggered by H3K9me2 demethylation drives estrogen-induced gene expression. Science 319: 202-206.

Pollock JA, Larrea MD, Jasper JS, McDonnell DP, McCafferty DG. 2012. Lysine-specific histone demethylase 1 inhibitors control breast cancer proliferation in ER $\alpha$-dependent and -independent manners. ACS Chem Biol 7: 1221-1231.

Prusevich P, Kalin JH, Ming SA, Basso M, Givens J, Li X, Hu J, Taylor MS, Cieniewicz AM, Hsiao PY, et al. 2014. A selective phenelzine analogue inhibitor of histone demethylase LSD1. ACS Chem Biol 9: 1284-1293.

Quirarte GL, Roozendaal B, McGaugh JL. 1997. Glucocorticoid enhancement of memory storage involves noradrenergic activation in the basolateral amygdala. Proc Natl Acad Sci 94: 14048-14053.

Rai G, Kawamura A, Tumber A, Liang Y, Vogel JL, Arbuckle JH, Rose NR, Dexheimer TS, Foley TL, King ON, et al. 2010. Discovery of ML324, a JMJD2 demethylase inhibitor with demonstrated antiviral activity. Probe Reports from the NIH Molecular Libraries Program, Bethesda, MD.

Rose NR, Ng SS, Mecinovic J, Lienard BM, Bello SH, Sun Z, McDonough MA, Oppermann U, Schofield CJ. 2008. Inhibitor scaffolds for 2-oxoglutarate-dependent histone lysine demethylases. J Med Chem 51: 7053-7056.

Rose NR, Woon EC, Kingham GL, King ON, Mecinovic J, Clifton IJ, Ng SS, Talib-Hardy J, Oppermann U, McDonough MA, et al. 2010. Selective inhibitors of the JMJD2 histone demethylases: Combined nondenaturing mass spectrometric screening and crystallographic approaches. J Med Chem 53: 1810-1818.

Rose NR, Woon EC, Tumber A, Walport LJ, Chowdhury R, Li XS, King ON, Lejeune C, Ng SS, Krojer T, et al. 2012. Plant growth regulator daminozide is a selective inhibitor of human KDM2/7 histone demethylases. J Med Chem 55: 6639-6643.

Rotili D, Tomassi S, Conte M, Benedetti R, Tortorici M, Ciossani G, Valente S, Marrocco B, Labella D, Novellino E, et al. 2014. Pan-histone demethylase inhibitors simultaneously targeting Jumonji $\mathrm{C}$ and lysine-specific demethylases display high anticancer activities. $J$ Med Chem 57: 42-55.

Sakaki H, Okada M, Kuramoto K, Takeda H, Watarai H, Suzuki S, Seino S, Seino M, Ohta T, Nagase S, et al. 2015. GSKJ4, a selective Jumonji H3K27 demethylase inhibitor, effectively targets ovarian cancer stem cells. Anticancer Res 35: 6607-6614.

Sakurai M, Rose NR, Schultz L, Quinn AM, Jadhav A, Ng SS, Oppermann U, Schofield CJ, Simeonov A. 2010. A miniaturized screen for inhibitors of Jumonji histone demethylases. Mol Biosyst 6: 357-364.

Sankar S, Theisen ER, Bearss J, Mulvihill T, Hoffman LM, Sorna V, Beckerle MC, Sharma S, Lessnick SL. 2014. Reversible LSD1 inhibition interferes with global EWS/ETS transcriptional activity and impedes Ewing sarcoma tumor growth. Clin Cancer Res 20: 4584-4597.

Sareddy GR, Nair BC, Krishnan SK, Gonugunta VK, Zhang QG, Suzuki T, Miyata N, Brenner AJ, Brann DW, Vadlamudi RK. 2013. KDM1 is a novel therapeutic target for the treatment of gliomas. Oncotarget 4: 18-28.

Sayegh J, Cao J, Zou MR, Morales A, Blair LP, Norcia M, Hoyer D, Tackett AJ, Merkel JS, Yan Q. 2013. Identification of small molecule inhibitors of Jumonji AT-rich interactive domain 1B (JARID1B) histone demethylase by a sensitive high throughput screen. J Biol Chem 288: $9408-$ 9417. 
A. Jambhekar et al.

Schenk T, Chen WC, Gollner S, Howell L, Jin L, Hebestreit K, Klein HU, Popescu AC, Burnett A, Mills K, et al. 2012. Inhibition of the LSD1 (KDM1A) demethylase reactivates the all-trans-retinoic acid differentiation pathway in acute myeloid leukemia. Nat Med 18: 605-611.

Schildhaus HU, Riegel R, Hartmann W, Steiner S, Wardelmann E, Merkelbach-Bruse S, Tanaka S, Sonobe H, Schule R, Buettner R, et al. 2011. Lysine-specific demethylase 1 is highly expressed in solitary fibrous tumors, synovial sarcomas, rhabdomyosarcomas, desmoplastic small round cell tumors, and malignant peripheral nerve sheath tumors. Hum Pathol 42: 1667-1675.

Schiller R, Scozzafava G, Tumber A, Wickens JR, Bush JT, Rai G, Lejeune C, Choi H, Yeh TL, Chan MC, et al. 2014. A cell-permeable ester derivative of the JmjC histone demethylase inhibitor IOX1. ChemMedChem 9: 566-571.

Schmidt DM, McCafferty DG. 2007. trans-2-Phenylcyclopropylamine is a mechanism-based inactivator of the histone demethylase LSD1. Biochemistry 46: 4408-4416.

Schmitt ML, Hauser AT, Carlino L, Pippel M, Schulz-Fincke J, Metzger E, Willmann D, Yiu T, Barton M, Schule R, et al. 2013. Nonpeptidic propargylamines as inhibitors of lysine specific demethylase 1 (LSD1) with cellular activity. J Med Chem 56: 7334-7342.

Schror K. 1997. Aspirin and platelets: The antiplatelet action of aspirin and its role in thrombosis treatment and prophylaxis. Semin Thromb Hemost 23: 349-356.

Sekirnik R, Rose NR, Thalhammer A, Seden PT, Mecinovic J, Schofield CJ. 2009. Inhibition of the histone lysine demethylase JMJD2A by ejection of structural $\mathrm{Zn}(\mathrm{II})$. Chem Commun (Camb) 42: 6376-6378.

Sharma SV, Lee DY, Li B, Quinlan MP, Takahashi F, Maheswaran S, McDermott U, Azizian N, Zou L, Fischbach MA, et al. 2010. A chromatin-mediated reversible drug-tolerant state in cancer cell subpopulations. Cell 141: 69-80.

Shi Y, Lan F, Matson C, Mulligan P, Whetstine JR, Cole PA, Casero RA, Shi Y. 2004. Histone demethylation mediated by the nuclear amine oxidase homolog LSD1. Cell 119: 941-953.

Shi YJ, Matson C, Lan F, Iwase S, Baba T, Shi Y. 2005. Regulation of LSD1 histone demethylase activity by its associated factors. Mol Cell 19: 857-864.

Shi L, Sun L, Li Q, Liang J, Yu W, Yi X, Yang X, Li Y, Han X, Zhang Y, et al. 2011. Histone demethylase JMJD2B coordinates $\mathrm{H} 3 \mathrm{~K} 4 / \mathrm{H} 3 \mathrm{~K} 9$ methylation and promotes hormonally responsive breast carcinogenesis. Proc Natl Acad Sci 108: 7541-7546.

Shih JC, Wu JB, Chen K. 2011. Transcriptional regulation and multiple functions of MAO genes. J Neur Trans 118: 979-986.

Simon LS, Mills JA. 1980. Nonsteroidal antiinflammatory drugs (second of two parts). N Engl J Med 302: 12371243.

Singh MM, Manton CA, Bhat KP, Tsai WW, Aldape K, Barton MC, Chandra J. 2011. Inhibition of LSD1 sensitizes glioblastoma cells to histone deacetylase inhibitors. Neuro Oncol 13: 894-903.

Sorna V, Theisen ER, Stephens B, Warner SL, Bearss DJ, Vankayalapati H, Sharma S. 2013. High-throughput virtual screening identifies novel $N^{\prime}$-(1-phenylethylidene)benzohydrazides as potent, specific, and reversible LSD1 inhibitors. J Med Chem 56: 9496-9508.
Stavropoulos P, Blobel G, Hoelz A. 2006. Crystal structure and mechanism of human lysine-specific demethylase- 1 . Nat Struct Mol Biol 13: 626-632.

Suva ML, Rheinbay E, Gillespie SM, Patel AP, Wakimoto H, Rabkin SD, Riggi N, Chi AS, Cahill DP, Nahed BV, et al. 2014. Reconstructing and reprogramming the tumorpropagating potential of glioblastoma stem-like cells. Cell 157: 580-594.

Suzuki T, Ozasa H, Itoh Y, Zhan P, Sawada H, Mino K, Walport L, Ohkubo R, Kawamura A, Yonezawa M, et al. 2013. Identification of the KDM2/7 histone lysine demethylase subfamily inhibitor and its antiproliferative activity. J Med Chem 56: 7222-7231.

Thalhammer A, Mecinovic J, Loenarz C, Tumber A, Rose NR, Heightman TD, Schofield CJ. 2011. Inhibition of the histone demethylase JMJD2E by 3-substituted pyridine 2,4-dicarboxylates. Org Biomol Chem 9: 127-135.

Theisen ER, Gajiwala S, Bearss J, Sorna V, Sharma S, JanatAmsbury M. 2014. Reversible inhibition of lysine specific demethylase 1 is a novel anti-tumor strategy for poorly differentiated endometrial carcinoma. BMC Cancer 14: 752.

Tortorici M, Borrello MT, Tardugno M, Chiarelli LR, Pilotto S, Ciossani G, Vellore NA, Bailey SG, Cowan J, O'Connell $\mathrm{M}$, et al. 2013. Protein recognition by short peptide reversible inhibitors of the chromatin-modifying LSD1/ CoREST lysine demethylase. ACS Chem Biol 8: 16771682.

Tschank G, Raghunath M, Gunzler V, Hanauske-Abel HM. 1987. Pyridinedicarboxylates, the first mechanism-derived inhibitors for prolyl 4-hydroxylase, selectively suppress cellular hydroxyprolyl biosynthesis. Decrease in interstitial collagen and Clq secretion in cell culture. Biochem J 248: 625-633.

Tsukada Y, Fang J, Erdjument-Bromage H, Warren ME, Borchers CH, Tempst P, Zhang Y. 2006. Histone demethylation by a family of JmjC domain-containing proteins. Nature 439: 811-816.

Ueda R, Suzuki T, Mino K, Tsumoto H, Nakagawa H, Hasegawa M, Sasaki R, Mizukami T, Miyata N. 2009. Identification of cell-active lysine specific demethylase 1-selective inhibitors. J Am Chem Soc 131: 17536-17537.

Valente S, Rodriguez V, Mercurio C, Vianello P, Saponara B, Cirilli R, Ciossani G, Labella D, Marrocco B, Monaldi D, et al. 2015a. Pure enantiomers of benzoylamino-tranylcypromine: LSD1 inhibition, gene modulation in human leukemia cells and effects on clonogenic potential of murine promyelocytic blasts. Eur J Med Chem 94: 163-174.

Valente S, Rodriguez V, Mercurio C, Vianello P, Saponara B, Cirilli R, Ciossani G, Labella D, Marrocco B, Ruoppolo G, et al. 2015b. Pure diastereomers of a tranylcyprominebased LSD1 inhibitor: Enzyme selectivity and in-cell studies. ACS Med Chem Lett 6: 173-177.

van Haaften G, Dalgliesh GL, Davies H, Chen L, Bignell G, Greenman C, Edkins S, Hardy C, O'Meara S, Teague J, et al. 2009. Somatic mutations of the histone H3K27 demethylase gene UTX in human cancer. Nat Genet 41: 521-523.

Van Rechem C, Black JC, Boukhali M, Aryee MJ, Graslund S, Haas W, Benes CH, Whetstine JR. 2015. Lysine demethylase KDM4A associates with translation machinery and regulates protein synthesis. Cancer Discov 5: 255-263. 
van Zutven LJ, Onen E, Velthuizen SC, van Drunen E, von Bergh AR, van den Heuvel-Eibrink MM, Veronese A, Mecucci C, Negrini M, de Greef GE, et al. 2006. Identification of NUP98 abnormalities in acute leukemia: JARID1A (12p13) as a new partner gene. Genes Chromosomes Cancer 45: 437-446.

Vasilatos SN, Katz TA, Oesterreich S, Wan Y, Davidson NE, Huang Y. 2013. Crosstalk between lysine-specific demethylase 1 (LSD1) and histone deacetylases mediates antineoplastic efficacy of HDAC inhibitors in human breast cancer cells. Carcinogenesis 34: 1196-1207.

Vianello P, Botrugno OA, Cappa A, Dal Zuffo R, Dessanti P, Mai A, Marrocco B, Mattevi A, Meroni G, Minucci S, et al. 2016. Discovery of a novel inhibitor of histone lysinespecific demethylase 1A (KDM1A/LSD1) as orally active antitumor agent. J Med Chem 59: 1501-1517.

Wada T, Koyama D, Kikuchi J, Honda H, Furukawa Y. 2015. Overexpression of the shortest isoform of histone demethylase LSD1 primes hematopoietic stem cells for malignant transformation. Blood 125: 3731-3746.

Wang J, Scully K, Zhu X, Cai L, Zhang J, Prefontaine GG, Krones A, Ohgi KA, Zhu P, Garcia-Bassets I, et al. 2007. Opposing LSD1 complexes function in developmental gene activation and repression programmes. Nature 446: $882-887$.

Wang Y, Zhang H, Chen Y, Sun Y, Yang F, Yu W, Liang J, Sun L, Yang X, Shi L, et al. 2009. LSD1 is a subunit of the NuRD complex and targets the metastasis programs in breast cancer. Cell 138: 660-672.

Wang L, Chang J, Varghese D, Dellinger M, Kumar S, Best AM, Ruiz J, Bruick R, Pena-Llopis S, Xu J, et al. 2013. A small molecule modulates Jumonji histone demethylase activity and selectively inhibits cancer growth. Nat Commun 4: 2035.

Wang J, Telese F, Tan Y, Li W, Jin C, He X, Basnet H, Ma Q, Merkurjev D, Zhu X, et al. 2015a. LSD1n is an H4K20 demethylase regulating memory formation via transcriptional elongation control. Nat Neurosci 18: 1256-1264.

Wang M, Liu X, Guo J, Weng X, Jiang G, Wang Z, He L. 2015b. Inhibition of LSD1 by Pargyline inhibited process of EMT and delayed progression of prostate cancer in vivo. Biochem Biophys Res Commun 467: 310-315.

Wang Q, Wei J, Su P, Gao P. 2015c. Histone demethylase JARID1C promotes breast cancer metastasis cells via down regulating BRMS1 expression. Biochem Biophys Res Commun 464: 659-666.

Wang Y, Zhu Y, Wang Q, Hu H, Li Z, Wang D, Zhang W, Qi B, $\mathrm{Ye} \mathrm{J,} \mathrm{Wu} \mathrm{H}$, et al. 2016. The histone demethylase LSD1 is a novel oncogene and therapeutic target in oral cancer. Cancer Lett. 374: 12-21.

Webby CJ, Wolf A, Gromak N, Dreger M, Kramer H, Kessler B, Nielsen ML, Schmitz C, Butler DS, Yates JR 3rd, et al. 2009. Jmjd6 catalyses lysyl-hydroxylation of U2AF65, a protein associated with RNA splicing. Science 325: 90-93.

Wetzel S, Wilk W, Chammaa S, Sperl B, Roth AG, Yektaoglu A, Renner S, Berg T, Arenz C, Giannis A, et al. 2010. A scaffold-tree-merging strategy for prospective bioactivity annotation of $\gamma$-pyrones. Angew Chem Int Ed Engl 49: 3666-3670.

Whetstine JR, Nottke A, Lan F, Huarte M, Smolikov S, Chen Z, Spooner E, Li E, Zhang G, Colaiacovo M, et al. 2006. Reversal of histone lysine trimethylation by the JMJD2 family of histone demethylases. Cell 125: 467-481.

Willmann D, Lim S, Wetzel S, Metzger E, Jandausch A, Wilk W, Jung M, Forne I, Imhof A, Janzer A, et al. 2012. Impairment of prostate cancer cell growth by a selective and reversible lysine-specific demethylase 1 inhibitor. Int J Cancer 131: 2704-2709.

Wissmann M, Yin N, Muller JM, Greschik H, Fodor BD, Jenuwein T, Vogler C, Schneider R, Gunther T, Buettner $\mathrm{R}$, et al. 2007. Cooperative demethylation by JMJD2C and LSD1 promotes androgen receptor-dependent gene expression. Nat Cell Biol 9: 347-353.

Woon EC, Tumber A, Kawamura A, Hillringhaus L, Ge W, Rose NR, Ma JH, Chan MC, Walport LJ, Che KH, et al. 2012. Linking of 2-oxoglutarate and substrate binding sites enables potent and highly selective inhibition of JmjC histone demethylases. Angew Chem Int Ed Engl 51: 1631-1634.

Wu CY, Hsieh CY, Huang KE, Chang C, Kang HY. 2012. Cryptotanshinone down-regulates androgen receptor signaling by modulating lysine-specific demethylase 1 function. Int J Cancer 131: 1423-1434.

Wu F, Zhou C, Yao Y, Wei L, Feng Z, Deng L, Song Y. 2016. 3-(Piperidin-4-ylmethoxy)pyridine containing compounds are potent inhibitors of lysine specific demethylase 1. J Med Chem 59: 253-263.

Yamane K, Tateishi K, Klose RJ, Fang J, Fabrizio LA, Erdjument-Bromage H, Taylor-Papadimitriou J, Tempst P, Zhang Y. 2007. PLU-1 is an H3K4 demethylase involved in transcriptional repression and breast cancer cell proliferation. Mol Cell 25: 801-812.

Yang ZQ, Imoto I, Fukuda Y, Pimkhaokham A, Shimada Y, Imamura M, Sugano S, Nakamura Y, Inazawa J. 2000. Identification of a novel gene, GASC1, within an amplicon at 9p23-24 frequently detected in esophageal cancer cell lines. Cancer Res 60: 4735-4739.

Yang M, Culhane JC, Szewczuk LM, Jalili P, Ball HL, Machius M, Cole PA, Yu H. 2007. Structural basis for the inhibition of the LSD1 histone demethylase by the antidepressant trans-2-phenylcyclopropylamine. Biochemistry 46: 8058-8065.

Ye Q, Holowatyj A, Wu J, Liu H, Zhang L, Suzuki T, Yang ZQ. 2015. Genetic alterations of KDM4 subfamily and therapeutic effect of novel demethylase inhibitor in breast cancer. Am J Cancer Res 5: 1519-1530.

Zheng YC, Duan YC, Ma JL, Xu RM, Zi X, Lv WL, Wang MM, Ye XW, Zhu S, Mobley D, et al. 2013. Triazole-dithiocarbamate based selective lysine specific demethylase 1 (LSD1) inactivators inhibit gastric cancer cell growth, invasion, and migration. J Med Chem 56: 8543-8560.

Zhou Y, Li Y, Wang WJ, Xiang P, Luo XM, Yang L, Yang SY, Zhao YL. 2015. Synthesis and biological evaluation of novel (E)- $\mathrm{N}^{\prime}$-(2, 3-dihydro-1H-inden-1-ylidene) benzohydrazides as potent LSD1 inhibitors. Bioorg Med Chem Lett doi: 10.1016/j.bmcl2015.06.054. 


\section{$\&_{\mathrm{CSH}}^{\infty} \&$ Cold Spring Harbor

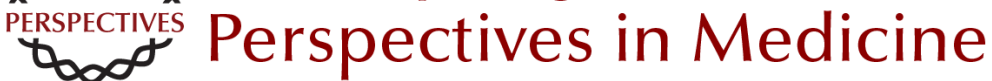

\section{Histone Lysine Demethylase Inhibitors}

Ashwini Jambhekar, Jamie N. Anastas and Yang Shi

Cold Spring Harb Perspect Med 2017; doi: 10.1101/cshperspect.a026484 originally published online October 6, 2016

\section{Subject Collection Chromatin Deregulation in Cancer}

\section{Mixed-Lineage Leukemia Fusions and Chromatin in Leukemia \\ Andrei V. Krivtsov, Takayuki Hoshii and Scott A. Armstrong}

Targeting Cancer Cells with BET Bromodomain Inhibitors

Yali Xu and Christopher R. Vakoc

The Role of Nuclear Receptor-Binding SET

Domain Family Histone Lysine Methyltransferases

in Cancer

Richard L. Bennett, Alok Swaroop, Catalina Troche, et al.

SETting the Stage for Cancer Development:

SETD2 and the Consequences of Lost Methylation Catherine C. Fahey and lan J. Davis

ATRX and DAXX: Mechanisms and Mutations Michael A. Dyer, Zulekha A. Qadeer, David Valle-Garcia, et al.

DNMT3A in Leukemia

Lorenzo Brunetti, Michael C. Gundry and Margaret A. Goodell

Oncogenic Mechanisms of Histone H3 Mutations Daniel N. Weinberg, C. David Allis and Chao Lu

Nonhistone Lysine Methylation in the Regulation of Cancer Pathways

Scott M. Carlson and Or Gozani
TET2 in Normal and Malignant Hematopoiesis Robert L. Bowman and Ross L. Levine

Long Noncoding RNAs: At the Intersection of Cancer and Chromatin Biology Adam M. Schmitt and Howard Y. Chang

DNA Hypomethylating Drugs in Cancer Therapy Takahiro Sato, Jean-Pierre J. Issa and Patricia Kropf

The Chromodomain Helicase DNA-Binding Chromatin Remodelers: Family Traits that Protect from and Promote Cancer Alea A. Mills

Exploitation of EP300 and CREBBP Lysine Acetyltransferases by Cancer Narsis Attar and Siavash K. Kurdistani

Histone Lysine Demethylase Inhibitors Ashwini Jambhekar, Jamie N. Anastas and Yang Shi

Cohesin Mutations in Cancer Magali De Koninck and Ana Losada

MLL3/MLL4/COMPASS Family on Epigenetic Regulation of Enhancer Function and Cancer Christie C. Sze and Ali Shilatifard

For additional articles in this collection, see http://perspectivesinmedicine.cshlp.org/cgi/collection/ 